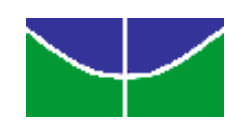

UNIVERSIDADE DE BRASÍLIA

Centro de Excelência em Turismo

\title{
A ÁGUA COMO ATRATIVO ECOTURÍSTICO E INSTRUMENTO MULTIPLICADOR DA \\ EDUCAÇÃO AMBIENTAL
}

Aline Paulo Nobre

Brasília, 2004. 


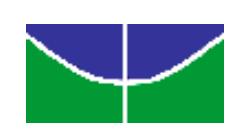

UNIVERSIDADE DE BRASÍLIA

Centro de Excelência em Turismo

\title{
A ÁGUA COMO ATRATIVO ECOTURÍSTICO E INSTRUMENTO MULTIPLICADOR DA EDUCAÇÃO AMBIENTAL
}

\author{
Aline Paulo Nobre \\ Orientadora: lara Lúcia Gomes Brasileiro \\ Monografia apresentada ao Centro de \\ Excelência em Turismo - CET, da Universidade de \\ Brasília como requisito para a obtenção do certificado \\ de Especialista em Ecoturismo.
}

Brasília, DF, 20 de setembro de 2004. 
UNIVERSIDADE DE BRASÍLIA

Centro de Excelência em Turismo

Curso de Especialização em Ecoturismo

\title{
A ÁGUA COMO ATRATIVO ECOTURÍSTICO \\ E INSTRUMENTO MULTIPLICADOR \\ DA EDUCAÇÃO AMBIENTAL
}

\author{
Aline Paulo Nobre
}

Banca Examinadora

Iara Lúcia Gomes Brasileiro, Dra.

Orientadora

Suzana Machado Pádua, Dra.

Membro da Banca

Brasília, DF, 20 de setembro de 2004. 
Nobre, Aline Paulo

A Água como atrativo ecoturístico e instrumento multiplicador da Educação Ambiental / Aline Paulo Nobre. $90 \mathrm{f}$.

Monografia (especialização) - Universidade de Brasília. Centro de Excelência em Turismo. Brasília, 2004.

Área de concentração - Turismo.

Orientadora - Iara Lúcia Gomes Brasileiro.

1. Ecoturismo. 2. Água. 3. Uso Sustentável. 4. Educação Ambiental. 


\section{ALINE PAULO NOBRE}

\section{A ÁGUA COMO ATRATIVO ECOTURÍSTICO \\ E INSTRUMENTO MULTIPLICADOR \\ DA EDUCAÇÃO AMBIENTAL}

Comissão Avaliadora

Professor(a) Orientador(a)

Brasília, DF, 20 de setembro de 2004. 


\section{DEDICATÓRIA}

Aos meus pais, irmãs, familiares e amigos por acreditarem em mim e também pelo apoio em mais esta etapa da vida.

Às pessoas que acreditam no potencial do Ecoturismo como atividade sustentável, nos benefícios que ele proporciona a todos que participam do seu desenvolvimento, possibilitando-Ihes uma melhor qualidade de vida e, sobretudo, que acreditam na sua capacidade e eficiência como alternativa de preservação do meio ambiente. 
A Deus, pela vida, consciência e oportunidades.

À Professora lara Brasileiro - que muito teve paciência comigo - pelo incentivo e ajuda fundamentais neste trabalho, além da sua generosidade de conhecimentos e informações.

Aos meus queridos pais, pelos valores e força transmitidos desde a infância.

Às minhas irmãs, familiares e amigos, a quem muito amo, pelo estímulo e votos de sucesso.

Aos colegas de curso, pela amizade e carinho e também pela ajuda e incentivos ofertados, revelando-se grandes amigos.

Aos colegas de trabalho, dos quais tive ajuda sempre disponível. 


\section{RESUMO}

O presente trabalho teve o intuito de abordar o ecoturismo como alternativa e proposta de um caminho para a mudança dos valores, conduta e práticas da sociedade relacionados ao meio ambiente, bem como sobre a necessidade do uso dos recursos naturais através das atividades e serviços turísticos desenvolvidos neste meio a fim de conscientizá-la sobre a questão ambiental no seu entendimento mais complexo. Para tanto, a educação ambiental - e também formal - e o recurso natural "água" são apresentados no trabalho como instrumentos fundamentais para o alcance e a concretização destes objetivos.

Palavra-Chave: Ecoturismo, Uso Sustentável, Água, Educação Ambiental 


\section{ABSTRACT}

The following research has the intention of approaching ecotourism as an alternative and proposal to a change of values, conducts and society practices related to the environment, as well as the necessity of natural resources usage through touristic activities and services developed in this environment, with the intention of raising society's awareness about environmental matters in its complex understanding. Therefore, environmental education - as well as formal and the natural resource "water" are presented in the following research as fundamental tools to achieve these goals.

Key-words: Ecotourism, Sustainable Usage, Water, Environmental Education 


\section{SUMÁRIO}

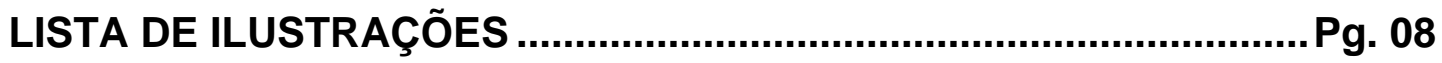

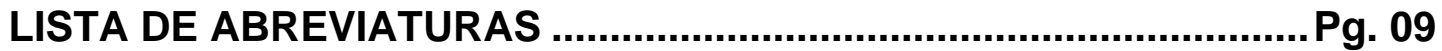

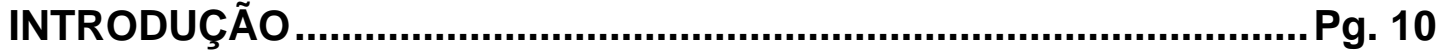

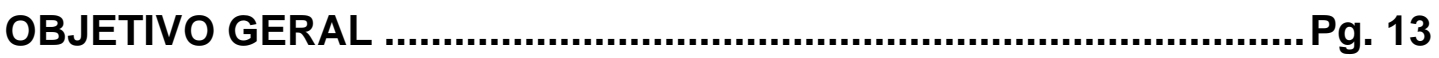

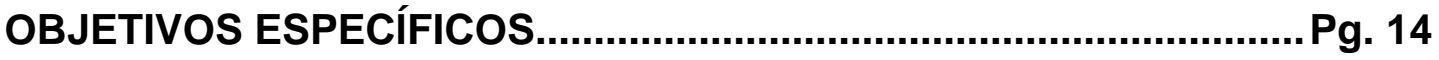

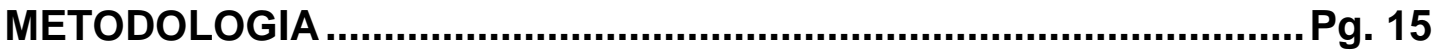

1. TURISMO E SUSTENTABILIDADE....................................................... 16

2. ECOLOGIA E ECOTURISMO …...............................................Pg. 22

3. ÉTICA PARA A GESTÃO AMBIENTAL E PARA O

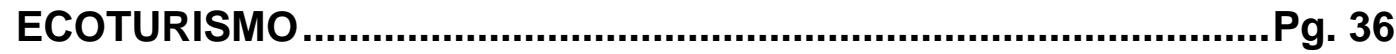

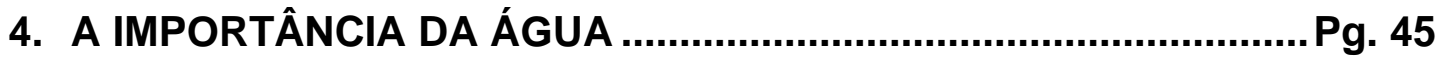

4.1 Situação atual dos recursos hídricos no mundo ..................Pg. 46

4.2 Gerenciamento: institucional $x$ indivíduo .............................Pg. 50

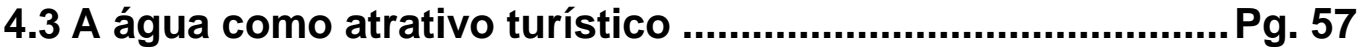

5. EDUCAÇÃO AMBIENTAL: ORIGEM, EVOLUÇÃO, PRINCÍPIOS E

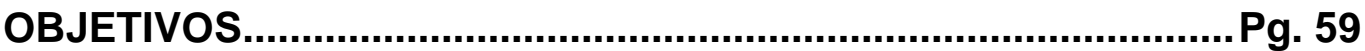

6. EDUCAÇÃO AMBIENTAL EM ATRATIVOS TURÍSTICOS .............Pg. 73

7. CONSIDERAÇÕES FINAIS ........................................................... 78

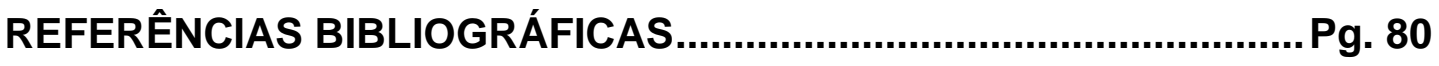

ANEXOS 


\section{LISTA DE ILUSTRAÇÕES}

FIGURA 1 - Bases da Sustentabilidade ............................................ 21

FIGURA 2 - Classificação em rede dos tipos de turismo...................Pg. 22

FIGURA 3 - Modelo de desenvolvimento econômico capitalista ....Pg. 30 FIGURA 4 - Quadro dos elementos de uma ética mundial para viver de forma sustentável ....................................................................Pg. 38

FIGURA 5 - Gráfico da distribuição total de água na Terra ..............Pg. 45

FIGURA 6 - Gráfico da distribuição de água doce na Terra.............Pg. 46

FIGURA 7-Gráfico da distribuição da água, da superfície e da população (em \% do total do País) ..................................................Pg. 51

FIGURA 8 - Quadro de gerenciamento da água..............................Pg. 55

FIGURA 9 - Diagrama dos objetivos da educação ambiental...........Pg. 62 
ANA Agência Nacional de Águas ANEEL .Agência Nacional de Energia Elétrica CNRH. .Conselho Nacional de Recursos Hídricos

E.A .Educação Ambiental ELETRONORTE .Centrais Elétricas do Norte do Brasil EMBRAPA .Empresa Brasileira de Pesquisa Agropecuária EMBRATUR Instituto Brasileiro de Turismo et. al. .E outros; et alii IBAMA Instituto Brasileiro do Meio Ambiente e dos Recursos Naturais Renováveis MEC Ministério da Educação MME. Ministério de Minas e Energia

OMT .Organização Mundial de Turismo

ONG. .Organização Não-Governamental ONU Organização das Nações Unidas op. cit. Citação, citado (a) PCN's. Parâmetros Curriculares Nacionais PNEA Política Nacional de Educação Ambiental PNMT. Programa Nacional de Municipalização do Turismo PNUMA Programa das Nações Unidas para o Meio Ambiente SEF. Secretaria Educação Fundamental SINGREH. Sistema Nacional de Gerenciamento de Recursos Hídricos SRH Secretaria de Recursos Hídricos UICN União Mundial para a Natureza UNEP Programa das Nações Unidas para o Ambiente WWF Fundo Mundial para a Natureza 


\section{INTRODUÇÃO}

A conquista do tempo livre e a necessidade de alcançar uma melhor qualidade de vida têm estimulado as pessoas a procurarem uma convivência mais intensa com a natureza, pois cada vez mais buscam novas experiências que possibilitem reflexões, satisfação e crescimento pessoal. Com isso, o conceito de qualidade de vida nos últimos anos tem sido associado diretamente às áreas verdes e aos demais recursos naturais.

Sendo assim, cada vez mais as viagens a lugares que proporcionam um contato direto com a natureza tornam-se procuradas como opção para a utilização do tempo livre. E dentre os segmentos do turismo que têm o ambiente natural como seu principal atrativo turístico, ou desenvolvem atividades em áreas naturais, vale destacar o Ecoturismo.

O Ecoturismo surge dentre estes segmentos como o mais completo, não apenas por possibilitar o contato das pessoas com a natureza, mas, também, permitindo a interação do visitante com a comunidade local, seus valores, hábitos e cultura, bem como o exercício da conscientização ambiental fora do ambiente natural, ou seja, nos grandes centros urbanos. Simultaneamente a todas essas vantagens concedidas aos ecoturistas, a atividade proporciona a esta comunidade, a geração de benefícios, melhorias e maior bem-estar.

Diante disto e do fato das áreas naturais representarem o principal atrativo para a realização da atividade ecoturística, é inevitável falar da grande diversidade dos recursos, da biodiversidade tanto vegetal quanto animal, e os lugares em que estão localizados. Muitas vezes esses lugares tornam-se os verdadeiros alvos da visitação, e, ainda, por meio da generosidade da natureza, podem variar nas mais diferentes formas de paisagens. Na grande maioria das 
vezes, a água faz parte destas paisagens, seja de forma discreta, quase imperceptível, ou de maneira fenomenal, como grandes cachoeiras e quedas d'água, balneários e piscinas naturais de beleza singular.

Entretanto, antes disso, a água é um recurso indispensável para a vida, de todos os seres na Terra. Mas com tantas mudanças e transformações decorrentes das interferências humanas no meio ambiente de forma não planejada e descontrolada, seja por desconhecimento dos envolvidos, ou simplesmente devido ao crescimento idealizado e buscado a qualquer preço pela economia capitalista, a natureza tem apresentado ao longo dos anos os resultados destas ações. Ações que acabam por necessitar de outras ações para minimizar e remediar os impactos negativos impostos ao meio natural, além de buscar a melhor forma de uso e aproveitamento dos recursos naturais, principalmente, da água por sua relevância indiscutível. Assim, faz-se necessária a busca por um novo modelo de vida, com novas gestões e diferentes atitudes da sociedade sobre o meio ambiente e para com o próximo, assegurando o direito de todos ao meio ambiente ecologicamente equilibrado.

A partir dessa idéia, entende-se que o Ecoturismo, por meio de seus princípios e objetivos, juntamente com aqueles que compõem a Educação Ambiental (E.A.), como uma ferramenta de desenvolvimento e conscientização da sociedade. O segmento permite um contato direto dos seus praticantes com a natureza, por meio de seus atrativos, possibilitando a reflexão e iniciativa de novos hábitos de consumo da água nas atividades que suprem desde as necessidades básicas até aquelas que possibilitam as realizações pessoais, como o ócio e o lazer. A água torna-se, portanto, não apenas um atrativo ecoturístico, independente da atividade que seja nela realizada (esportiva, contemplativa, medicinal, entre outras), mas um instrumento multiplicador da Educação Ambiental. 
Mais correto seria se a sociedade tivesse consciência da importância dos recursos naturais, e neste caso, da água, para a manutenção do equilíbrio do meio ambiente e existência de vida, antes de ter qualquer contato com o meio natural. E uma vez que a atual situação difere deste anseio, e que existe a possibilidade de mudanças, destaca-se aqui o Ecoturismo e seu papel na conscientização dos seus praticantes e na sua participação para a preservação do meio ambiente e seus recursos.

A falta de conhecimento ou mesmo o descaso por parte da sociedade sobre a relevância dos recursos naturais e também sobre a sua renovação (ou não), como é a situação da água hoje, tem levado muitas pessoas a usarem e abusarem destes recursos, sem refletir nas conseqüências de suas atitudes. Ou seja, percebe-se que não existe ainda por parte da sociedade como um todo a preocupação com o uso correto e sustentável dos recursos naturais, com ações preventivas e econômicas que ajudem na manutenção da qualidade e quantidade ideal para uso de todos. Além disso, devido ao individualismo que atua fortemente hoje na sociedade, os recursos naturais, de maneira geral, acabam sendo utilizados de forma que beneficiam apenas uma minoria da mesma. No caso da água, por exemplo, existe um verdadeiro comércio mundial dirigido por algumas multinacionais com o objetivo único de venda e lucro. Um recurso e um bem de direito de todos, que nem todos têm acesso ou condições (financeiras, sanitárias, entre outras) para utilizá-lo de acordo com suas necessidades.

Por essa lógica, entende-se que a prática do Ecoturismo e da Educação Ambiental é indispensável para mudar os paradigmas de crescimento e desenvolvimento que a sociedade criou e que ainda segue. São instrumentos que permitem uma reaproximação do ser humano com a natureza e refazem a ligação e a relação existente entre eles, resultando em novos comportamentos e atitudes. 


\section{OBJETIVO GERAL}

Este trabalho visa apresentar o ecoturismo e a educação ambiental como instrumentos de conscientização ecológica e de sensibilização da sociedade a partir do contato do ecoturista com o meio ambiente.

Portanto, entende-se que o ecoturismo, por meio dos atrativos naturais/culturais e da educação ambiental, proporciona e possibilita novos hábitos de consumo e de uso dos recursos naturais, o que poderá, aos poucos (re) direcionar a sociedade para sua responsabilidade em manter o bom estado do meio ambiente como um todo. Para que isso aconteça, é preciso incentivar a educação ambiental como forma de integração da sociedade e do meio ambiente, no sentido de resgatar a cidadania, o respeito à natureza e, conseqüentemente, a adoção de uma conduta correta quanto aos recursos naturais, entendendo-os como bens comuns a todos.

A partir dessa interação com o ambiente natural, seja por meio de trilhas ecológicas, passeios em atrativos naturais, interpretação ambiental, entre outros, são possíveis reflexões sobre a maneira correta para a utilização dos recursos naturais, sobretudo da água, e a sua importância para a vida. 


\section{OBJETIVOS ESPECIFICOS}

- Destacar o meio ambiente e os recursos naturais como importantes fornecedores de matéria-prima e viabilizadores do bem-estar e da qualidade de vida e enfatizar a necessidade de sua preservação;

- Enfatizar a importância do uso correto (sustentável) dos recursos naturais e da conscientização ecológica para garantir o seu equilíbrio, a sua manutenção e a existência dos seres vivos;

- Apresentar a importância da água para a vida;

- Abordar de maneira geral a questão da correta e má utilizações dos recursos hídricos no mundo e em particular no país, e os seus efeitos à saúde e à natureza;

- Destacar o planejamento e a participação da sociedade para o bom gerenciamento dos recursos hídricos;

- Apresentar o Ecoturismo como segmento capaz de contribuir na formação de multiplicadores da conscientização ecológica;

- Estimular o conhecimento e a valorização do meio ambiente por meio da Educação Ambiental associada ao atrativo turístico "água”;

- Relacionar a importância de uma gestão correta dos recursos hídricos tanto para o seu uso convencional como também para o desenvolvimento de atividades sustentáveis, como é o caso do Ecoturismo. 


\section{METODOLOGIA}

Para a elaboração do trabalho, foi realizada pesquisa teórica em bibliografias, periódicos e internet dos conceitos de ecoturismo, educação ambiental, sustentabilidade e da água defendidos por diversos autores. A partir dos pressupostos teóricos recorridos foi feita a reflexão sobre os benefícios do ecoturismo e da educação ambiental, bem como sobre as vantagens da sua utilização para a idealização de uma proposta para mudança dos métodos de uso dos recursos naturais para alcançar o desenvolvimento sustentável e a conscientização ecológica sobre a importância dos mesmos, sobretudo, da água. 


\section{TURISMO E SUSTENTABILIDADE}

Muitos dos conceitos de turismo existentes enfocam apenas os dados quantitativos para usos estatísticos, os quais são insuficientes para defini-lo. O turismo atualmente "é resultado de processos sociais e culturais não inteiramente quantificáveis e que são imprescindíveis para a sua compreensão..." (Molina e Rodríguez, 2001, pág. 12).

Segundo Andrade (apud Embratur, 2001), turismo

É o conjunto de princípios que regulam as viagens de prazer ou de utilidade, tanto no que diz respeito à ação pessoal dos viajantes ou turistas como no que se refere à ação daqueles que se ocupam em recebê-los e facilitam seus deslocamentos.

De acordo com Wahab (apud Correia, 2002, pág. 95), o turismo pode ser compreendido como

(...) atividade humana intencional que serve como meio de comunicação e como elo de interação entre os povos, tanto dentro de um mesmo país como fora dos limites geográficos dos países. Envolve o deslocamento temporário de pessoas para outra região, país ou continente, visando a satisfação de necessidades outras que não o exercício de uma função remunerada.

A compreensão sobre o que realmente é a atividade turística torna-se fundamental para a elaboração e implementação de ações que resulte em melhores rendimentos globais, sejam financeiros ou sociais. 
Ao longo dos anos, o turismo tem se destacado dentre as demais atividades econômicas pela geração de renda e empregos que proporciona às localidades que apresentam atrativos de relevância, seja pela sua beleza cênica ou singularidade na natureza. Dados da Organização Mundial de Turismo (OMT) (apud in WWF, 2003, pág. 11), confirmam que o turismo é o setor econômico de maiores índices de crescimento em todo o mundo, e apresenta a expansão de $60 \%$ das suas atividades na década de 90 . Ainda de acordo a Organização, a atividade no Brasil ainda é emergente, mas apresenta crescimento intenso nos últimos anos.

De maneira geral, os atrativos locais são disponibilizados em forma de produto e exigem da atividade um planejamento e segmentação para atender aos visitantes-consumidores e seus mais variados objetivos de viagem. Essa demanda fez surgir vários segmentos do Turismo, como por exemplo, o religioso, o cultural, o histórico, de melhor idade, o ecoturismo, de negócios, de lazer, que necessitam de ações de desenvolvimento comum entre eles e aquelas específicas de interesse de cada um.

Por outro lado, o aumento das viagens e a busca das pessoas por novos lugares resultaram o consumismo de uma forma geral, caracterizando, muitas vezes, o turismo como massivo, tornando-se, assim, um grande vilão a essas localidades. O turismo, quando realizado dessa forma, exerce uma pressão às comunidades e suas culturas e também ao meio ambiente, resultando em seu desequilíbrio, e, muitas vezes, em perdas e prejuízos significativos, que podem ser irreversíveis. Isso acontece pela falta de compreensão por parte dos planejadores - da iniciativa pública ou privada - e empreendedores turísticos sobre a importância de um planejamento integral, considerando todas as partes envolvidas na realização da atividade do turismo. O turismo sem um planejamento sobre os impactos sociais e ambientais pode estar voltado apenas ao lucro, causando prejuízos ou perdas no meio e local de realização da atividade. 
Quando o turismo é planejado a partir de uma perspectiva reducionista como, por exemplo, a partir de aspectos econômicos ou exclusivamente financeiros, cria desequilíbrios evidentes nas demais dimensões de uma sociedade e de sua cultura que the servem de contexto. Os conflitos se acirram, ficando difícil controlá-los numa etapa posterior.

(Molina e Rodríguez, 2001, pág. 10)

A atividade turística tem utilizado de forma abusiva os espaços (naturais ou não) em função do consumismo que transforma o seu serviço em produto e mercadoria. Ela utiliza esses espaços de maneira predatória ao implementar sua infra-estrutura pesada e inadequada, gerar e estimular a especulação imobiliária, dentre outros, tornando-se massivo e insustentável. Esta situação agrava-se ainda mais com a ausência de educação voltada ao turismo e ambiental, o que faz dele uma atividade de interesses conflitantes com o meio.

"O turismo é uma atividade (...) que permeia quase todos os segmentos da sociedade e da economia, e mantém relações com os mesmos, com profundas repercussões na cultura e no meio ambiente" (Correia, 2002, pág. 85). E por ser uma atividade de processos e relações sociais, culturais e ambientais complexas, o turismo deve ter no seu planejamento um instrumento para minimizar as interferências e os impactos resultantes de sua realização. De acordo com Molina e Rodríguez (2001, pág. 10), "o planejamento integral deve reconhecer esta complexidade do turismo, processá-la e instrumentalizá-la para promover mudanças que atuem como alavancas do desenvolvimento".

Quando realizado em áreas naturais, o turismo deve ter suas ações planejadas eficazmente para que a visitação não resulte em impactos negativos e acarrete danos que venham a descaracterizar o atrativo e a própria cultura local. Um exemplo de um segmento do turismo que visa a preservação do meio 
ambiente e o uso sustentável dos recursos naturais é o Ecoturismo, atividade que existe a partir da interação e relação do visitante com o ambiente natural e as comunidades locais e sua cultura.

Sendo assim, para promover o desenvolvimento da atividade turística devese buscar um planejamento com técnicas e métodos apropriados para sua viabilização e para a sustentabilidade, tanto da atividade quanto do meio ambiente, com a preocupação de manter as características essenciais dos patrimônios turístico, cultural e natural.

A sustentabilidade pode ser compreendida como

(...) uma relação entre sistemas econômicos dinâmicos e sistemas ecológicos maiores, também dinâmicos e que, no entanto, modificam-se mais lentamente, de tal forma que a vida humana pode continuar indefinidamente, os indivíduos podem prosperar e as culturas humanas podem desenvolver-se - mas, também, uma relação na qual os efeitos das atividades humanas permanecem dentro de limites que não deterioram a saúde e integridade de sistemas auto-organizados que fornecem o contexto ambiental para estas atividades.

(Norton, 1992, pág. 25 apud Faria e Carneiro, 2001, pág. 13)

De acordo com Mangel et. al. (apud Faria e Carneiro, 2001, pág. 15), a sustentabilidade pode também ser entendida através de três diferentes aspectos: (1) uso sustentável, (2) crescimento sustentável e (3) desenvolvimento sustentável. O primeiro acontece quando o ser humano utiliza racionalmente os recursos, possibilitando a sua reposição natural e a sua constante renovação. O segundo resulta quando o crescimento econômico faz uso limitado de recursos, ao mesmo tempo em que realiza um controle do crescimento populacional e do 
consumo individual de recursos. O último, conforme o autor, somente é possível quando promovido a partir do necessário e obrigatório uso sustentável dos recursos renováveis, por meio de ações para melhoria social e econômica das populações.

O Instituto Brasileiro de Turismo (Embratur) (apud Correia, 2002, pág. 86), utiliza a figura a seguir para representar, em um cenário global, as bases da sustentabilidade do turismo.

FIGURA 1 - BASES DA SUSTENTABILIDADE

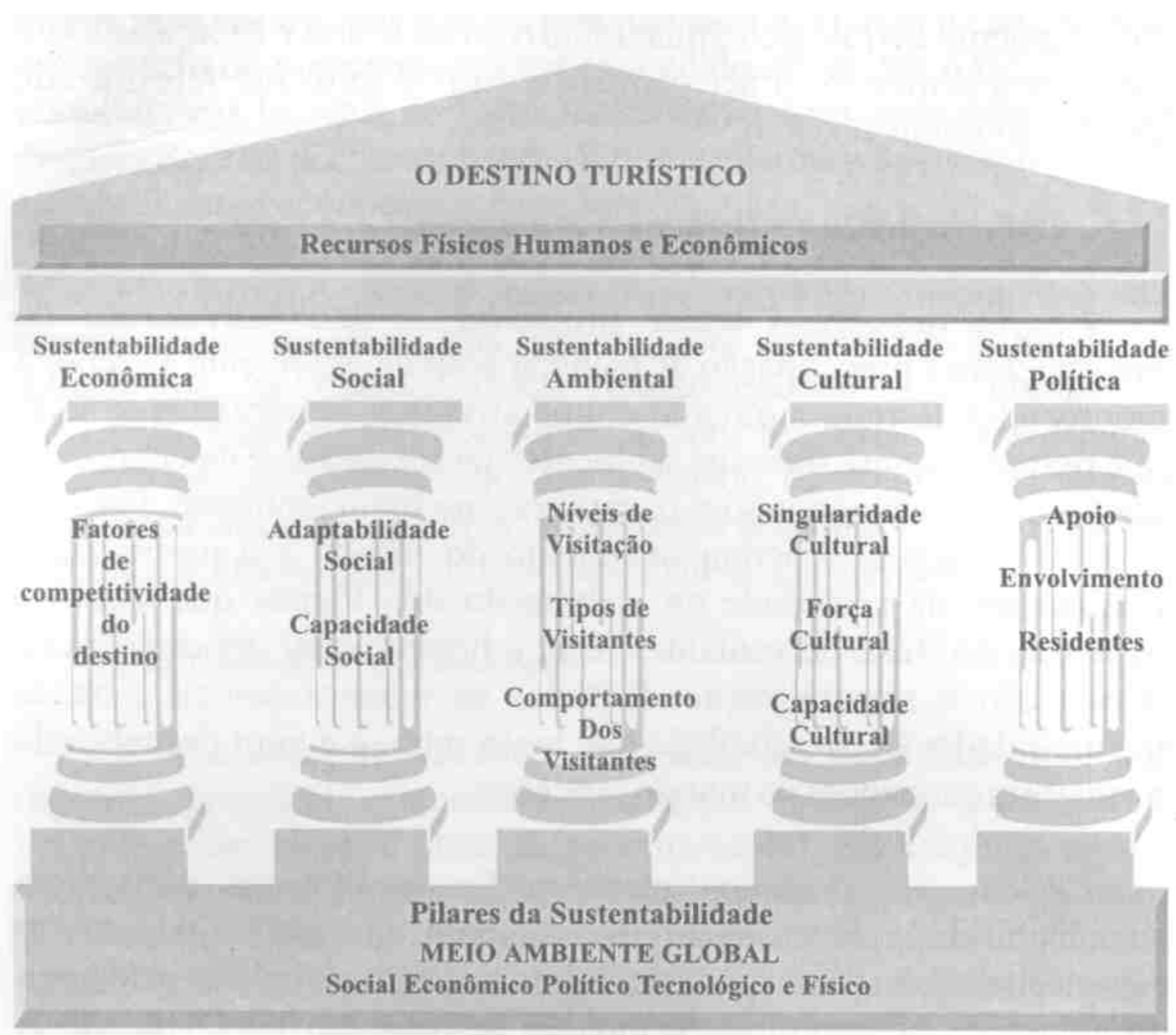

Fonte: EMBRATUR / OMT / PNMT Guia para Oficinas de Treinamento (pág. 35) Brasília, 1994. 
Conforme apresentado na figura, a sustentabilidade do turismo depende de outros aspectos que são fundamentais para o desenvolvimento da atividade. Também é importante salientar que, para que o turismo seja de fato sustentável, as bases para a sua realização, que são os ambientes naturais e a cultura, devem ser conservadas. Portanto, a conservação do meio ambiente e do patrimônio cultural são exigências imprescindíveis para buscar a sustentabilidade da atividade turística, exigindo, portanto, o uso responsável dos recursos naturais e estimulando a valorização da cultura local.

Com a finalidade de reforçar a importância da sustentabilidade ecológica para o desenvolvimento do turismo, indiferentemente dos seus tipos, segmentos, e de suas características, a Figura 2 apresenta as definições que o mesmo deve realizar para a elaboração dos seus serviços e atividades. A questão da sustentabilidade é central em qualquer situação turística, conforme pode ser observado.

\section{FIGURA 2 - CLASSIFICAÇÃO EM REDE DOS TIPOS DE TURISMO}

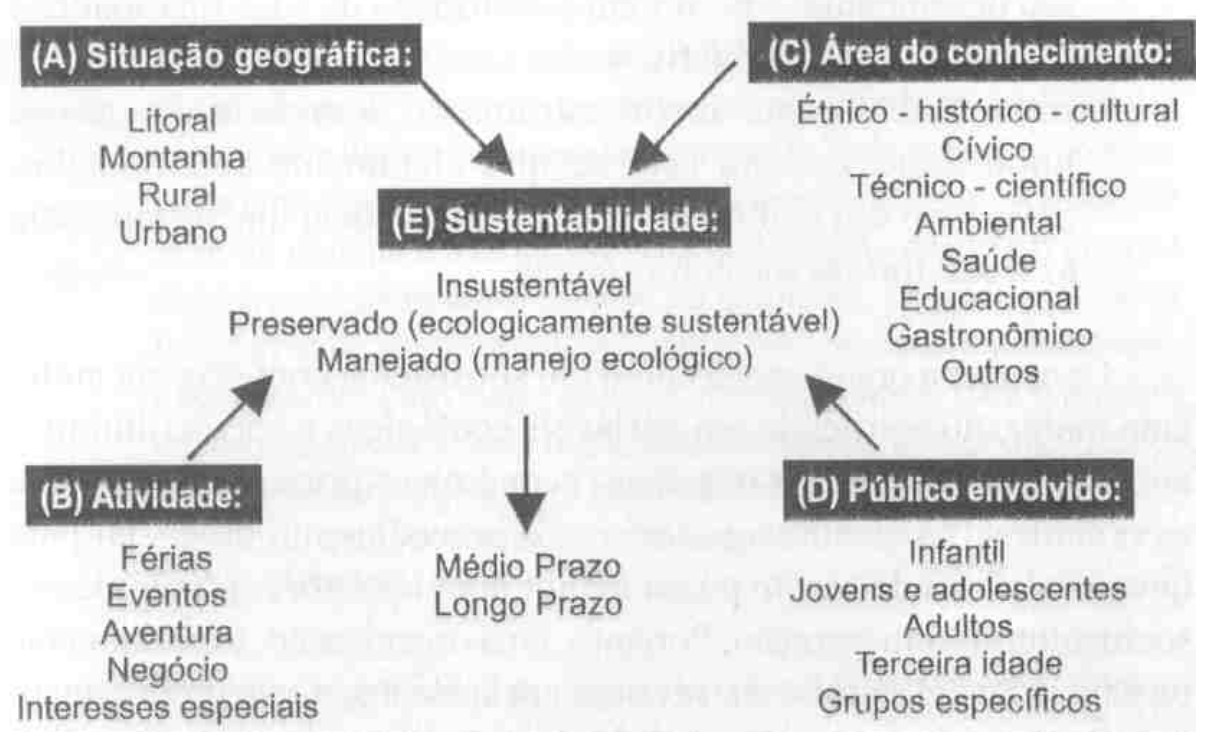

FONTE: Faria e Carneiro, 2001, pág. 


\section{ECOLOGIA E ECOTURISMO}

A palavra ecologia resulta da junção das palavras gregas oikos e logia que significam, respectivamente, casa e ciência. Portanto, pode ser compreendida como a ciência que estuda a grande casa (Planeta Terra) em sua complexidade, ou seja, estuda a natureza por meio das relações e interações entre os seres vivos e destes com o meio do qual fazem parte. Conforme Lutzenberger (apud. Boff, 2004, pág. 18), "a ecologia é a ciência da sinfonia de vida, é a ciência da sobrevivência".

A ecologia não visa meramente a conservação do meio ambiente natural e a idéia do ambientalismo (que não é tão simples), "mas a compreensão das relações de intercâmbio e de transformação de energia entre os seres vivos, envolvendo a relação de todas as coisas existentes umas com as outras", como destaca Coriolano (apud Barreto e Tamanini, 2002, pág. 38). Desta forma, a ecologia se estende por todas as ciências e por isso abrange todos os ramos do conhecimento. Independentemente da atividade que se realiza, cada pessoa deve buscar com equilíbrio ecológicos ou valores / posturas sempre a menor interferência na natureza.

Deve ser desenvolvido, na sociedade em geral, sobretudo naquelas parcelas com maior conhecimento e acesso a informações - para que possa defender o meio ambiente de maiores agressões -, o sentimento de preocupação constante com a "saúde" da natureza e a compreensão da necessidade de aprender a cuidá-la, pois temos como sociedade e parte da natureza este dever a fim de mantê-la saudável para a existência da vida na Terra. No livro Saber cuidar. Ética do humano - compaixão pela terra, publicado em 1999, Boff afirma ser necessário "desenvolver a ética do cuidado", pois este pode resultar preocupação, inquietação e o sentido de responsabilidade nas pessoas (pág. 134). Estes sentimentos são essenciais e devem ser constantes para despertar a sociedade 
como um todo como a principal responsável por um meio ambiente melhor, tarefa inicialmente difícil, mas que deve ser feita conscientemente por cada um, para tornar-se simples mais à frente, e possível de perpetuar-se. A educação ambiental, portanto, surge como uma alternativa capaz de sensibilizar a humanidade para a necessidade de cuidar da natureza, provocando-lhe o sentimento de co-responsabilidade para com o meio ambiente e seu semelhante. Enfim, a estratégia que se faz necessária é aquela que objetiva a mudança do estado de consciência, possibilitada por experiências e atividades educativas e interpretativas realizadas no meio natural e, sobretudo, por meio da E.A.

A ecologia acontece em toda a parte, em todo o meio ambiente. Meio ambiente que na verdade é o ambiente por inteiro. Trata-se de um grande sistema de relações de interdependência e troca entre os seres e destes com o meio, que deve ter a auto-regulação como característica para manter-se sempre equilibrado. Entretanto, atualmente, o monitoramento da qualidade e quantidade dos recursos, bem como da qualidade do meio ambiente como um todo, tem se mostrado como importante meio de avaliar as ações desenvolvidas nas áreas degradadas.

Para compreender melhor o significado da expressão meio ambiente, recorre-se a algumas denominações que lhe são atribuídas por diferentes especialistas. Para exemplo, seguem as seguintes definições de meio ambiente:

Conjuntos de fatores bióticos (os seres vivos) ou abióticos (físicoquímicos) do habitat suscetíveis de terem efeitos diretos ou indiretos sobre os seres vivos e, compreende-se, sobre o homem.

(Touffet - dicionário francês de ecologia. Reigota apud MEC; SEF, 2001, pág. 71) 
O que circunda um indivíduo ou um grupo. A noção de meio ambiente engloba, ao mesmo tempo, os meios cósmico, geográfico, físico e o meio social, com suas instituições, sua cultura, seus valores. Esse conjunto constitui um sistema de forças que exerce sobre o indivíduo e nas quais ele reage de forma particular, segundo seus interesses e suas capacidades.

(Silliamy, no Dicionário Enciclopédico de Psicologia. Reigota apud MEC; SEF, 2001, pág. 71)

O lugar determinado ou percebido, onde os elementos naturais e sociais estão em relações dinâmicas e em interação. Essas relações implicam processos de criação cultural e tecnológica e processos históricos e sociais de transformação do meio natural e construído.

(Reigota apud MEC; SEF, 2001, pág. 72)

De acordo com Ferreira (2000), meio ambiente é o "conjunto de condições e influências naturais que cercam um ser vivo ou uma comunidade, e que agem sobre eles".

Para a WWF (2003, pág. 435), meio ambiente é o "conjunto de todas as condições, leis e influências externas circundantes, de ordem física, química e biológica, que interagem com um organismo, população ou uma comunidade".

Embora todas as definições apresentadas considerem o ser humano como parte do meio ambiente, esta idéia não era defendida por toda a comunidade científica até pouco tempo. E considerando a relação humana com a natureza, certamente suas ações certamente irão se refletir no meio ambiente e nos seus recursos, devendo assim, serem repensadas e adequadas diante da fragilidade 
do meio natural e da necessidade de manutenção do seu equilíbrio para a garantia de sua existência.

O meio ambiente ecologicamente equilibrado é assegurado pela Constituição Brasileira como direito de todos; bem de uso comum e essencial para a continuidade de uma boa qualidade de vida. Além disso, a Constituição atribui o dever de preservá-lo e defendê-lo não apenas ao Poder Público como também à sociedade. Entretanto, esta preservação pode estar longe de ser alcançada. E isso pode vir a tornar-se fato porque a sociedade diante de suas necessidades - básicas ou não - se vê no direito de utilizar os seus recursos naturais de forma desordenada, despreocupada com a sua integridade, ou seja, com a manutenção de suas características, no que diz respeito tanto à sua qualidade quanto à sua quantidade e durabilidade, no sentido de ser mantida para conhecimento e uso das futuras gerações.

Portanto, segundo Coriolano (apud Barreto e Tamanini, 2002, pág. 38), a ecologia é transdisciplinar, ou seja, transcende as disciplinas acadêmicas e por isso faz-se necessária em qualquer atividade humana.

No que tange à educação, as informações básicas e relevantes sobre o meio ambiente, que devem ser de alcance e conhecimento do ser humano desde a infância, são disponibilizadas formalmente, hoje, graças às políticas e aos programas desenvolvidos pelo Ministério da Educação, tais como a Política Nacional de Educação Ambiental $(P N E A)^{1}$ e os Parâmetros Curriculares Nacionais (PCN's), além dos documentos relevantes originados por eventos e reuniões nacionais e internacionais sobre o assunto.

\footnotetext{
${ }^{1}$ A Política Nacional de Educação Ambiental (PNEA), definida pela Lei Federal no 9795, de 27 de abril de 1999 e regulamentada pelo Decreto № 4.281, de 25/06/2002, tem suas diretrizes voltadas aos princípios, aos objetivos, às linhas de atuação e às estratégias de implementação da EA.
} 
"A Política Nacional de Educação Ambiental é uma proposta programática de promoção da educação ambiental em todos os setores da sociedade. Diferente de outras Leis, não estabelece regras ou sanções, mas estabelece responsabilidades e obrigações (MEC, 2004)". De acordo com este Ministério, a partir destas ações viabilizadas pela PNEA, a educação ambiental é institucionalizada, tem seus princípios legalizados e se transforma em objeto de políticas públicas, além de fornecer à sociedade condições para cobrança da sua promoção. Assim, a médio e principalmente a longo prazo, é possível que esta evolução da educação ambiental resulte no despertar da sociedade para novos hábitos e preocupações com o meio ambiente de uma forma geral, o que lhe proporcionará mais à frente, melhorias na qualidade vida, do meio e com isso maior bem-estar. Já os PCN's, por meio do Programa Parâmetros em Ação - Meio Ambiente na Escola, abrangem a temática ambiental no ensino fundamental, desenvolvendo atividades interdisciplinares que possibilitam abordar o assunto nas mais variadas disciplinas, de maneira transversal.

Desta forma, em consonância com Boff (2004, pág. 17), a ecologia "(...) não substitui os saberes particulares com os seus paradigmas específicos, seus métodos e resultados (...)". As ciências devem sim continuar seus estudos e pesquisas - a sua construção -, mas sempre atentas umas às outras devido à interdependência existente em seus objetos de estudo.

Embora os princípios ecológicos tenham sido aplicados por muitos povos antigos há milhares de anos, a ecologia surgiu e foi sistematizada há pouco mais de um século; é uma ciência nova. Mais recente ainda é o destaque atribuído ao ambientalismo. De acordo com Pires (2002, pág. 47), "a história contemporânea do ambientalismo pode ser abordada a partir do momento em que começam a ser geradas no pós-guerra dos anos 1940 muitas pesquisas científicas voltadas para os recursos naturais do planeta". Entretanto, anteriormente a essas iniciativas, aconteceu a recuperação econômica dos países ocidentais, após a guerra, e os avanços de suas indústrias e tecnologias, destacando-se os setores dos transportes e telecomunicações. Essas melhorias possibilitaram o acesso às 
informações de interesse geral e o deslocamento das pessoas por todo o globo, inicialmente, de parcelas da sociedade que tinham maior conhecimento e condições financeiras. Daí o aumento das viagens.

A partir dessas pesquisas, nos anos 1960, consoante Pires (2002, pág. 48), os resultados e informações importantes produzidas pela sociedade científica, e até então restritas, começam a se tornar conhecidas pelos segmentos sociais mais informados, principalmente dos países desenvolvidos. Essas informações alertavam desde a destruição de áreas naturais em diferentes partes do planeta e deterioração ambiental, até as descobertas naturalistas e botânicas para fim medicinal, entre outros, a partir de exemplares característicos das florestas tropicais e equatoriais das regiões periféricas da Terra.

Segundo o mesmo autor, pelo pioneirismo e importância das informações, a mídia enfocou aquelas mais alarmantes, que poderiam ser notícia. A difusão e o conseqüente aumento dessas informações sobre os problemas ambientais desencadearam nos anos 1970 os movimentos ambientalistas. Estes se organizaram contra o então sistema econômico vigente (e ainda atual), que visava a produção e o progresso a qualquer custo, se estabeleceram e se fortificaram devido paralelamente ao seu surgimento outros movimentos ativistas estarem na plenitude de suas atuações, tais como os hippies, esquerda revolucionária, movimentos estudantis. Apesar de diferentes entre si, havia uma identificação entre as causas defendidas por cada um.

Entretanto, concomitantemente a esses acontecimentos, cada vez mais um número maior de pessoas busca e se interessa pela realização das viagens, o que resulta na exploração desenfreada dos espaços naturais e urbanos, caracterizando o turismo de massas. Este turismo descontrolado e despreocupado com a degradação dos espaços e da estrutura social e econômica das populações locais, bem como sobre a qualidade ambiental dos destinos alcança sua plenitude no início dos anos 1970. 
Consoante com o que afirma Pires (2002, pág. 35), alguns fatos e acontecimentos amplamente constatados são exemplos dos problemas gerados pela massificação do turismo:

- expropriação e ocupação violenta do território por parte das forças e agentes turísticos;

- especulação imobiliária e da terra;

- expulsão e marginalização de populações locais;

- ruptura dos valores culturais e desequilíbrio da economia local;

- degradação de culturas tradicionais;

- manipulação da memória e da herança coletiva;

- violação de lugares sagrados;

- segregação étnica;

- formação de "guetos" turísticos;

- desvios de comportamento e prostituição de mulheres e adolescentes;

- comportamento grosseiro e insensível de turistas nos destinos estrangeiros;

- poluição e destruição do meio natural;

- imperialismo econômico de corporações transnacionais, neocolonialismo;

- evasão de divisas para o exterior.

A percepção desses problemas por parte das instituições e organismos ligados ao turismo, bem como por pesquisadores da atividade, resultou nas primeiras críticas ao turismo de massas. Devido a lógica e consistência das informações que apontavam o turismo como o responsável pelos problemas acima citados, o assunto tomou maior significado, estendendo-se a grupos de estudos qualificados e autoridades da área. Essas manifestações contrárias ao desenvolvimento desordenado do turismo foram, aos poucos, constituindo-se em temas de eventos e encontros de âmbito regional e mesmo internacional a fim de 
discutir a forma de desenvolvimento do turismo e os impactos sociais, ambientais, econômicos e culturais por ele ocasionados.

Dos anos 1950 aos 1970, vários encontros marcaram uma época de progresso quanto à preocupação com o ambiente natural e o seu estado, na verdade, o estado da Terra. Durante esse tempo, ocorreram mudanças significativas no perfil dos movimentos ambientalistas, que surgiram preservacionistas, e mais tarde tornaram-se conservacionistas. Mas foi realmente a partir de meados dos anos 1970 que os encontros começaram a ser realizados em uma constância maior em diferentes partes do mundo para discutir o assunto, destacando-se pela concepção de novas idéias e princípios éticos para redirecionar a atividade.

O reconhecimento e a valorização das idéias em torno de propostas alternativas para o desenvolvimento da atividade fizeram com que surgissem novos modelos de turismo, os quais eram realizados em menor escala, sem necessidade de tantas mudanças no meio para a viabilização de instalações e acomodações possibilitando também um maior envolvimento das comunidades locais. O modelo de crescimento e desenvolvimento vigente na época foi criticado por visar apenas o progresso, a utilização dos recursos e espaços naturais de maneira descontrolada e provocar a homogeneização das culturas (Ver Figura 3). 


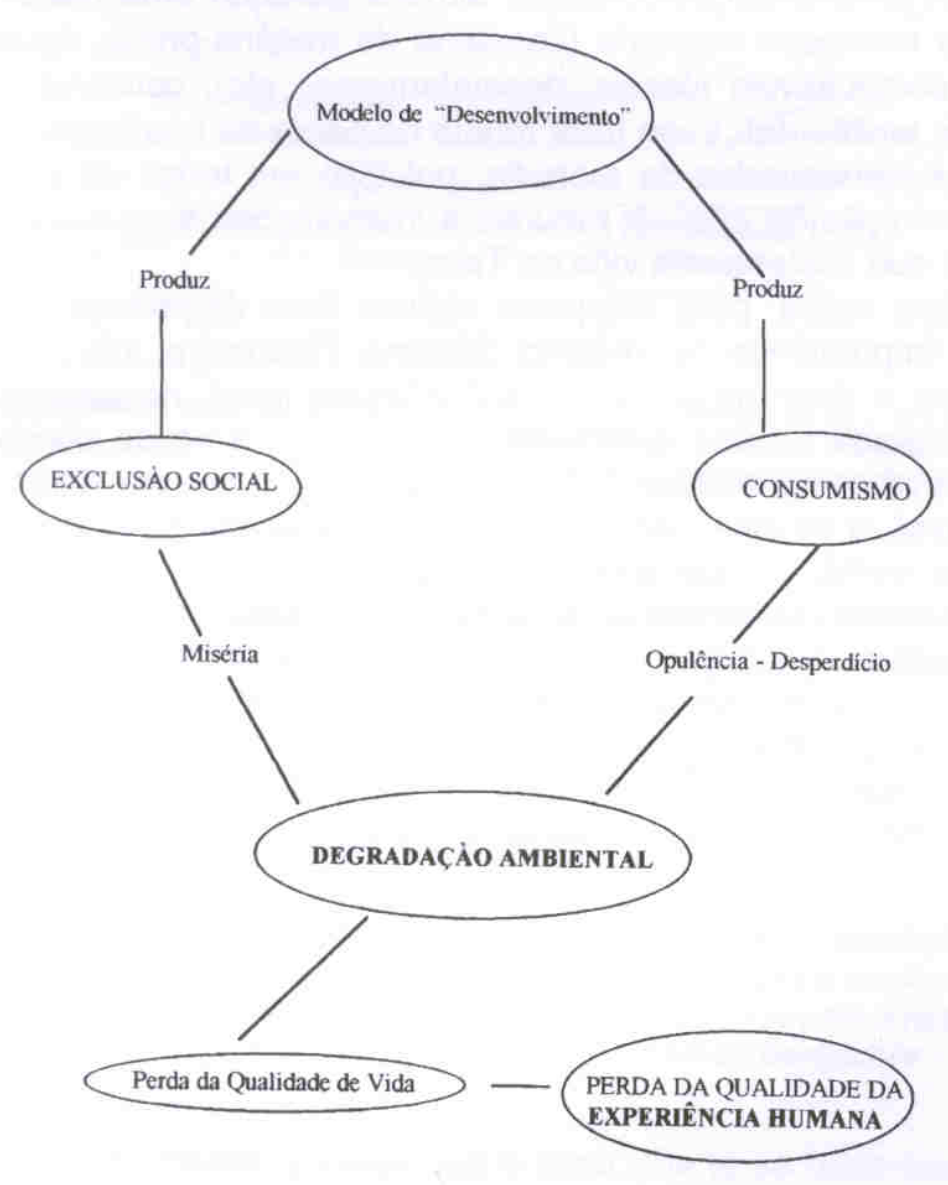

FONTE: Dias, 1997, Pág. 13

Como sugere Ceballos-Lascurain (apud Pires, 2002, pág. 43), o "novo paradigma ambiental" - surgido na década de 1970 - sobrepõe o "paradigma social dominante", que predominava os anos 1950 e 1960. Ele surge como reação de desapontamento com os problemas sociais e ambientais surgidos ou agravados na vigência do "paradigma social dominante". Trata-se do "novo ecologismo", que coloca Diegues (apud Pires, 2002, pág. 43), com surgimento a partir das manifestações estudantis de 1968 na Europa e Estados Unidos.

Assim novas alternativas de turismo começam a ser desenvolvidas em diferentes partes do mundo, buscando evitar conseqüências como aquelas 
causadas pelo turismo de massas. Denominações como "turismo alternativo", "turismo brando", "turismo de descoberta" e "turismo responsável" começam a aparecer nos encontros como propostas, tendo suas características definidas bem como seus princípios e objetivos. A partir daí, começa a ser delineado o que seria o ecoturismo, praticado inicialmente por jovens aventureiros e mochileiros dos países desenvolvidos, que tinham ideais de mudanças do sistema econômico e de hábitos de consumo e que eram interessados por um meio ambiente melhor e sem tanta degradação; para tanto, buscavam desbravar espaços naturais desconhecidos mais exóticos e longínquos.

O ecoturismo tem seu surgimento ocorrido no período dos anos 1960 e 1970, quando os grandes temas ambientais, depois de difundidos na comunidade científica, começam a sensibilizar também a opinião pública.

Entende-se como um segmento do turismo realizado em ambientes naturais que interage o visitante com o meio ambiente, com a população local e sua cultura. É baseado no contato dos visitantes com áreas naturais e culturas autênticas, cuja originalidade possibilita experiências pessoais de crescimento. $O$ ecoturismo possibilita o desenvolvimento sustentável por meio de atividades desenvolvidas nestes locais utilizando os recursos da natureza de forma responsável, planejada.

De acordo com a Embratur (1994, pág. 19), Ecoturismo é

(...) um segmento da atividade turística que utiliza, de forma sustentável, o patrimônio natural e cultural, incentiva sua conservação e busca a formação de uma consciência ambientalista através da interpretação do ambiente, promovendo o bem-estar das populações envolvidas. 
Mowforth (apud Pires, 2002, pág. 149) aborda o ecoturismo como

(...) uma prática planejada do turismo na qual o desfrute da natureza e o saber sobre as formas de vida e o seu relacionamento com o ambiente são proporcionados ao mesmo tempo; é uma atividade que não resulta na deterioração do ambiente que fornece um apoio para a conservação dos recursos naturais e culturais, produzindo em conseqüência benefícios econômicos mais voltados para a população.

Para o Instituto de Ecoturismo do Brasil, ecoturismo

(...) é a prática de turismo de lazer, esportivo ou educacional, em áreas naturais, que se utiliza de forma sustentável dos patrimônios natural e cultural, incentiva a sua conservação, promove a formação de consciência ambientalista e garante o bem estar das populações envolvidas.

(apud EMBRATUR, 2004)

De acordo com o Instituto, o nome "ecoturismo" é novíssimo, surgiu oficialmente em 1985, e somente em 1987 foi criada a Comissão Técnica Nacional constituída pelo Instituto Brasileiro do Meio Ambiente e dos Recursos Naturais Renováveis (IBAMA) e a Embratur, ordenando as atividades neste campo.

Os principais objetivos do Ecoturismo são:

- promover e desenvolver turismo com bases cultural e ecologicamente sustentáveis; 
- promover e incentivar investimentos em conservação dos recursos culturais e naturais utilizados;

- fazer com que a conservação beneficie materialmente comunidades envolvidas, pois somente servindo de fonte de renda alternativa estas se tornarão aliadas de ações conservacionistas;

- ser operado de acordo com critérios de mínimo impacto para ser uma ferramenta de proteção e conservação ambiental e cultural;

- educar e motivar pessoas através da participação e atividades.

O ecoturismo utiliza as belezas e paisagens naturais, a cultura e modo de vida de comunidades - principalmente as tradicionais - como atrativos aos visitantes. É uma forma de valorizar os patrimônios natural, histórico e cultural de uma dada localidade, região ou nação. Ele é diferente dos demais segmentos turísticos exatamente porque utiliza os recursos naturais a um ritmo e volume que o meio ambiente consegue suportar e depois renová-los.

A implementação da sua infra-estrutura (serviços, equipamentos e alojamentos) deve causar o mínimo de impacto possível, uma vez que se trata de instalações e serviços desenvolvidos no meio natural, o qual deve ter o seu equilíbrio preservado. As relações de troca e interação entre as espécies dentro dos sistemas e entre eles devem ser respeitadas e mantidas. Por essa razão e pelo fato de que o próprio ecoturista se interessa, valoriza, e, portanto, dá preferência por instalações menos impactantes que possibilitam a preservação do meio ambiente, os planejadores e empreendedores ecoturísticos buscam cada vez mais seguir e respeitar os anseios dos seus clientes e da natureza, pesquisando e implementando novas tecnologias de baixo impacto.

Por tudo isso, o ecoturismo é evolutivo. Ele atende a estilos de vida que priorizam o ser humano e a natureza, e que saibam valorizar e estimular a relação e interação entre eles. O ecoturismo é uma viagem responsável, onde o praticante sabe o que está à procura ou subentende o que irá encontrar. É 
realizado para pequenos grupos e oferece a estes uma experiência significativa com o meio ambiente e consigo mesmo. Segundo Coriolano (apud Barreto e Tamanini, 2002, pág. 50), o ecoturismo trata-se de uma atividade econômicosocial integrada ao meio ambiente. A autora ainda afirma que "o que se busca é colocar o ecoturismo a serviço da conservação ambiental e do desenvolvimento, minimizando custos e maximizando benefícios".

Portanto, qualquer ação ou atividade para ser considerada ecoturística deverá apresentar os seguintes princípios básicos (Pires 2002, pág. 166):

- ênfase na natureza e nos valores culturais autênticos;

- minimização dos impactos ambientais;

- geração de benefícios para a comunidade local;

- difusão da consciência ecológica por meio da educação ambiental;

- compromisso com a conservação da natureza.

Coriolano (apud Barreto e Tamanini, 2002, pág. 35) afirma que para compreender tal atividade faz se necessário entender antes de tudo o que é ecologia e depois o que é turismo, uma vez que a explicação para o Ecoturismo deve ser encontrada a partir dos conceitos dessas duas ciências. Isso acontece pelo fato dessas duas ciências estarem conquistando uma posição de destaque cada vez maior no mundo atual. As razões para tal acontecimento, conforme a autora, são as seguintes: quanto à importância dada à ecologia: o isolamento da sociedade (menos favorecida e também daquela mais favorecida) e a destruição dos recursos naturais derivados de um modelo econômico capitalista que objetiva apenas o acúmulo de capital, independentemente que para tanto seja necessário o uso descontrolado dos recursos naturais e a destruição da natureza com suas ações não-planejadas sobre o meio ambiente. Já o destaque dado ultimamente para o turismo é devido à necessidade do ócio (este que foi possível graças à conquista do tempo livre) e conseqüentemente, pela criação de novos produtos e anseios da sociedade, direcionados ao tempo livre e ao lazer. Além disso, outra 
razão é que o turismo poderá tornar-se uma atividade de sustentação de um novo modelo de desenvolvimento.

Diante desse enfoque, que desperta questões sociais e a sensibilização do meio, é necessário um planejamento sério que contenha em sua estrutura estudos de viabilidade econômica, ambiental e social, bem como definições corretas da infra-estrutura, sistemas de monitoramento, estudos de impacto ambiental e social, de capacidade de carga, dentre outros fatores para o sucesso da implantação de atividades ecoturísticas. Além disso, e essencialmente, devem ser objetivos do ecoturismo e suas ferramentas, as bases educativas, de conservação da natureza e das culturas, as quais, segundo Coriolano (apud Barreto e Tamanini, 2002, pág. 36), são indispensáveis para a existência, firmação e prestígio do turismo. A educação ambiental, confirma-se, novamente, como uma alternativa para sensibilização e mobilização da sociedade, em busca de uma proposta que considere relevantes em seu planejamento as questões ambientais, que sejam desenvolvidas por meio de atividades educativas. 


\section{3. ÉTICA PARA A GESTÃO AMBIENTAL E PARA O TURISMO}

A complexidade e abrangência da questão ambiental devem-se aos questionamentos dos modelos de ocupação e apropriação da natureza (e seus recursos) pelos seres humanos, às relações humanas e aos modelos políticoeconômicos, os quais envolvem diferentes interações espaciais de âmbito local e global (MEC e SEF, 2001, pág. 59).

Segundo Boff (apud ELETRONORTE 2004), os cenários mundiais referentes ao estado do Planeta Terra mostram piora de ano para ano. A espécie humana já ocupou $83 \%$ do planeta, e ocupa devastadoramente os ecossistemas, prejudicando o equilíbrio ecológico. De acordo com o autor: "Exaurimos de maneira os recursos, grande parte deles não-renováveis que a Terra já ultrapassou em 20\% a sua capacidade de reposição e regeneração". Assim, torna-se necessário cada vez mais a tomada de ações e atitudes éticas na tentativa de minimizar os efeitos da (má) utilização dos recursos.

A gestão dos recursos naturais deve ser feita de forma que mantenha uma preocupação constante com sua correta utilização a fim de possibilitar a sua preservação e existência. Os recursos naturais devem ser geridos de maneira que não falte à manutenção das relações dos ecossistemas e também de forma que os resultados de sua utilização possam ser distribuídos e alcançados pelo maior número de pessoas. Eles devem estar disponíveis na natureza para uso de todos os seres, e não exclusivamente ao homem.

Entretanto, tais atitudes e ações não se limitam ao uso correto dos recursos naturais. Elas se estendem também à prioridade do uso e aos benefícios que podem ser gerados à sociedade. 
Ao observar aqueles que utilizam os recursos e a finalidade do seu uso percebemos que muitas vezes (na verdade, em sua grande maioria) esse processo se dá de acordo com as necessidades e desejos de pequenos grupos da sociedade. Grupos estes que agem de acordo com visão e interesses próprios, gerando conflitos entre si e um descontentamento da sociedade como um todo, pois tem a sua qualidade de vida e o meio ambiente alterados devido às ações daquela minoria. "Nesta perspectiva a coletividade não é um todo homogêneo, mas uma multiciplidade de partes com visões diferenciadas sobre a destinação dos recursos ambientais na sociedade" (IBAMA, 2002).

O homem deve ter como compromisso o respeito e o cuidado para com os outros seres e não apenas com a sua espécie, ou seja, para com o Planeta Terra por inteiro. Suas ações de zelo e preocupação devem ser expressas na forma de uma ética para possibilitar uma vida sustentável. Estratégias para formatar um plano para busca dessa ética, que deve ser apresentada nas práticas diárias indiferentemente de quem / que as sofre, podem ser entendidas como "um conjunto de princípios sólidos e de apelo moral para guiar a conduta humana" (UICN, PNUMA, WWF, 1991, pág. 13), os quais são relacionados no quadro a seguir. 


\section{FIGURA 4 - ELEMENTOS DE UMA ÉTICA MUNDIAL PARA VIVER DE FORMA SUSTENTÁVEL}

Todo ser humano é parte da comunidade dos seres vivos. Esta comunidade interliga todas as sociedades humanas - geraçōes presentes e futuras -, como também a humanidade, com o restante da natureza. Ela engloba tanto a diversidade cultural quanto a natural.

Todo ser humano tem os mesmos direitos fundamentais, incluindo: o direito à vida, à liberdade e à segurança pessoal; à liberdade de pensamento, consciência e religiāo; ao questionamento e à livre expressāo; à livre assembléia e associação; à participação no governo; à educação; e, dentro dos limites do Planeta Terra, aos recursos necessários para um padrāo de vida digno. Nenhuma comunidade ou nação tem o direito de privar qualquer outra de seus meios de subsistência.

Cada indivíduo e cada sociedade deve respeitar esses direitos, sendo responsável pela proteçăo deles.

Cada forma de vida deve ser respeitada, independentemente de seu valor para o homem. O desenvolvimento humano näo deve ameaçar a integridade da natureza ou a sobrevivência de outras espécies. As pessoas devem tratar dignamente todas as criaturas e protegê-las da crueldade, evitando o sofrimento e a morte desnecessários.

Todos devem ser responsáveis por seu próprio impacto sobre a natureza. As pessoas devem conservar os processos ecológicos e a diversidade da natureza. Os recursos devem ser usados apenas nos níveis realmente necessários e com eficiência, atentando para que o uso dos recursos renováveis seja sustentável.

continua... .

Todos devem ter como objetivo compartilhar os benefícios e custos do uso de recursos entre as comunidades e grupos interessados, entre as regiōes pobres e abastadas, e entre as geraçōes presente e futuras. Cada geração deve deixar para sua sucedânea um mundo pelo menos tão diverso e produtivo quanto aquele que herdou. $O$ desenvolvimento de uma sociedade ou geração não deve limitar as oportunidades de outras sociedades ou geraçōes.

A proteção dos direitos humanos e do restante da natureza é uma responsabilidade de âmbito mundial, que transcende as fronteiras culturais, ideológicas e geográficas. A responsabilidade é tanto coletiva quanto individual.

Fonte: UICN, PNUMA, WWF, 1991, pág. 14 
A ética é significativa e fundamental em um processo de mudanças pois direciona a conduta de cada indivíduo, e conseqüentemente, de cada sociedade. Cada pessoa deve preocupar-se com seus semelhantes e com as próximas gerações, como também a sociedade deve atentar-se a respeito da sua responsabilidade sobre as demais formas de vida; deve cuidar da natureza e não apenas utilizá-la como fonte de matéria-prima a fim de satisfazer as suas necessidades (UICN, PNUMA, WWF, 1991, pág. 13).

A ética da sociedade dominante atual é utilitarista e antropocêntrica. Considera o conjunto dos seres a serviço do ser humano que pode dispor deles a seu bel-prazer, atendendo a seus desejos e preferências. Acredita que o ser humano, homem e mulher, é a coroa do processo evolutivo e o centro do universo.

(Boff, 2004, pág. 21)

A proposta de uma ética para o mundo atual apresenta grande relevância, pois a transição das sociedades atuais para àquelas consideradas sustentáveis exigirá mudanças na maneira como as pessoas vêem as outras, os outros seres vivos, independentemente de sua importância para a humanidade, e também o próprio Planeta. Exigirá muita reflexão para avaliarem e mudarem suas necessidades e prioridades - abandonando o consumismo descontrolado de bens e de recursos - e, conseqüentemente, o seu comportamento. O limite dos desejos da humanidade e da vantagem (individual, principalmente) à custa da exploração de outras sociedades e espécies, deverá ser desenvolvido (Boff, 2004, pág. 21) para que cada indivíduo compreenda a necessidade de mudança e assimile este sentimento. Consoante Boff (2004, pág. 186): "O que pensamos e principalmente o que sentimos devem nos ajudar a renovar nossas atitudes".

A criação de uma ética é importante, sobretudo apoiada por organizações, indivíduos e grupos que trabalham, cada um a sua maneira, para o alcance de um 
mundo melhor, sejam eles relacionados ao meio ambiente e à natureza, sejam grupos humanistas que buscam a igualdade para todos (o que já deveria acontecer sem a organização das pessoas) e melhores condições de vida àqueles necessitados, e até mesmo as religiões. Conforme União Mundial para a Natureza (UICN), Programa das Nações Unidas para o Meio Ambiente (PNUMA) e Fundo Mundial para a Natureza (WWF) (1991, pág.13), o apoio dos segmentos religiosos é fundamental para que os objetivos dessa ética possam ser alcançados, pois eles já incentivam o respeito ao próximo e à natureza como criação divina.

Independentemente dos interesses e objetivos defendidos por cada um desses grupos divergirem entre si, a aliança entre eles deve acontecer para que a ética permeie todas as esferas da ação humana.

No âmbito do turismo, a OMT, por meio do Código Mundial de Ética do Turismo, elaborado em 1999, apresenta os princípios éticos para a realização e desenvolvimento da atividade turística de maneira responsável e saudável, tanto no que se refere às comunidades dos destinos e dos turistas, quanto à conservação dos recursos naturais e do meio ambiente. Princípios que visam a sustentabilidade do turismo e os deveres de cada ator participante da atividade.

Dentre os quarenta e oito princípios distribuídos nos dez artigos do documento, estão apresentados no trabalho aqueles que tratam o turismo como contribuinte para a compreensão e respeito mútuo entre homem e sociedades, instrumento de desenvolvimento individual e coletivo, fator de desenvolvimento sustentável e atividade benéfica para os países e para as comunidades de destino. São eles: 
Artigo 1 - Contribuição do turismo para a compreensão e respeito mútuo entre homem e sociedades:

1. A compreensão e a promoção dos valores éticos comuns à humanidade, num espírito de tolerância e de respeito pela diversidade das crenças religiosas, filosóficas e morais, são ao mesmo tempo fundamento e conseqüência de um turismo responsável. Os agentes do desenvolvimento turístico e os próprios turistas devem ter em conta as tradições e práticas sociais e culturais de todos os povos, incluindo as das minorias e populações autóctones, reconhecendo a sua riqueza.

Artigo 2 - $\underline{\text { o turismo, instrumento de desenvolvimento individual e coletivo }}$

1. O turismo, atividade geralmente associada ao repouso, à diversão, ao desporto, ao acesso à cultura e à natureza, deve ser concebido e praticado como meio privilegiado de desenvolvimento individual e coletivo. Praticado com a necessária abertura de espírito, constitui-se em um fator insubstituível de auto-educação, de tolerância mútua e de aprendizagem das diferenças legítimas entre povos e culturas, e de sua diversidade.

2. As atividades turísticas devem respeitar a igualdade entre homens e mulheres; devem tender a promover os direitos humanos e especialmente, os particulares direitos dos grupos mais vulneráveis, especificamente as crianças, os idosos, os deficientes, as minorias étnicas e os povos autóctones.

Artigo 3 - o turismo, fator de desenvolvimento sustentável

1. É dever de todos os agentes envolvidos no desenvolvimento turístico salvaguardar o ambiente e os recursos naturais, na perspectiva de um crescimento econômico sadio, contínuo e sustentável, capaz de 
satisfazer eqüitativamente as necessidades e as aspirações das gerações presentes e futuras.

2. Todos os tipos de desenvolvimento turístico que permitam economizar os recursos naturais raros e preciosos, principalmente a água e a energia, e que venham a evitar, na medida do possível, a produção de dejetos, devem ser privilegiados e encorajados pelas autoridades públicas nacionais, regionais e locais.

4. As infra-estruturas devem estar concebidas e as atividades turísticas programadas de forma a que seja protegido o patrimônio natural constituído pelos ecossistemas e a biodiversidade, e que sejam preservadas as espécies ameaçadas da fauna e da flora selvagens. Os agentes do desenvolvimento turístico, principalmente os profissionais, devem permitir que Ihes sejam impostas limitações ou obstáculos às suas atividades quando elas sejam exercidas em zonas particularmente sensíveis: regiões desérticas, polares ou de altas montanhas, zonas costeiras, florestas tropicais ou zonas úmidas, propícias à criação de parques naturais ou reservas protegidas.

5. O turismo de natureza e o ecoturismo são reconhecidos como formas de turismo especialmente enriquecedoras e valorizadoras, sempre que respeitem o patrimônio natural e as populações locais se ajustem à capacidade de carga dos locais turísticos.

Artigo 5 - O turismo, atividade benéfica para os países e para as comunidades de destino

1. As populações e comunidades locais devem ser associadas às atividades turísticas e participar eqüitativamente nos benefícios econômicos, sociais e culturais que geram, e sobretudo na criação de emprego direto ou indireto resultante. 
4. Os profissionais do turismo, especialmente os investidores, devem, conforme regulamentação estabelecida pelas autoridades públicas, proceder a estudos sobre o impacto dos seus projetos de desenvolvimento em relação ao entorno e aos meios naturais existentes. Devem, da mesma forma, prestar informações quanto aos seus futuros programas e aos impactos previstos, com a maior transparência e objetividade requerida, abrindo-se ao diálogo, nessas matérias, com as populações interessadas.

De acordo com a OMT, este documento (Código Mundial de Ética do Turismo) ajudará a minimizar os efeitos negativos do turismo no meio ambiente e no patrimônio cultural, aumentando, simultaneamente, os benefícios para os residentes nos destinos turísticos.

Entretanto, faz-se necessário somar a esta iniciativa o apoio para a formulação e criação de uma ética para se viver sustentavelmente. E como a ética define direitos e responsabilidades, cada indivíduo deverá respeitar o próximo e seus direitos. Com isso, muitas pessoas precisarão modificar suas atitudes para com o próximo e de maneira destacável para com a natureza, pois esta não suportará as agressões e atenderá as suas exigências por muito mais tempo. E os benefícios proporcionados por ela, não apenas ao homem como também aos demais seres, não mais estarão disponíveis, principalmente ao primeiro - devido ao seu mau uso - ao menos que este aprenda a cuidá-la e respeitá-la.

O respeito a outras formas de vida é mais fácil naquelas culturas e sociedades que acreditam estar a humanidade tanto à parte quanto fazendo parte da natureza. Esse respeito fica muito evidente nessas comunidades que vivem em contato com a natureza e em consonância com suas antigas tradições de cuidados para com ela.

(UICN, PNUMA, WWF, 1991, pág. 14) 
Diante disso, é certo que as comunidades tradicionais, autóctones e os povos indígenas podem contribuir à sociedade mundial com seus conhecimentos no sentido que estas possam redescobrir - embora tenha se passado muito tempo - a vida sustentável. Para isso, é fundamental compreender a atual questão ambiental e buscar medidas e ações que visam o cuidado do meio ambiente e o respeito para com ele e ao próximo. Segundo Boff (2004), "é preciso difundir a estratégia de cuidar do ambiente e, juntamente, cuidar da sociedade". 


\section{A IMPORTÂNCIA DA ÁGUA}

Se comparada aos demais recursos naturais existentes na Terra, a água pode ser considerada como um dos principais (senão o principal) devido a sua importância para a existência de vida no planeta. Ela mantém e representa um elo de ligação entre os ecossistemas, permitindo que realizem trocas resultando na interação entre seus sistemas.

A água é suporte para a vida, mas é também protagonista em diferentes ramos do conhecimento popular ou científico. Além da sua importância, tanto para os ambientes quanto para os seres vivos, ela tem papel fundamental e significado único, intransferível. Como exemplo da sua importância aos demais setores da sociedade pode-se citar a participação da água nas áreas de: Arte, História, Mitologia, Geografia, Língua Portuguesa, dentre outras.

Consoante Coimbra, Rocha e Beekman (1999, pág. 11), a água é

(...) um elemento essencial à vida, tanto como constituinte biológico dos seres vivos, como meio de vida de várias espécies vegetais e animais, como elemento representativo de valores sociais e culturais e até como fator de produção de vários bens de consumo final e intermediário.

A água tem possibilidade de múltiplos usos, tais como: agricultura (irrigação), abastecimento humano e animal, indústria, pesca / aqüicultura, saneamento básico (recepção de resíduos), preservação do meio ambiente, navegação, turismo / recreação / cultura, geração de energia. 


\subsection{Situação atual dos recursos hídricos no mundo}

Sabe-se que a água ocupa $2 / 3$ da superfície da Terra e também que a sua distribuição ocorre da seguinte forma: 97,5\% dela é salgada e 2,5\% é doce (ANA apud Revista Isto É, 2002, págs. 86 e 87). Do que se refere à água doce existente no planeta, $77,2 \%$ encontram-se em geleiras e calotas polares, 22,4\% localizamse em lençóis subterrâneos, 0,04\% na atmosfera e apenas 0,36\% estão disponíveis nas águas de superfície na forma de rios, lagos e pântanos (ver Figuras 5 e 6).

FIGURA 5 - DISTRIBUIÇÃO TOTAL DE ÁGUA NA TERRA

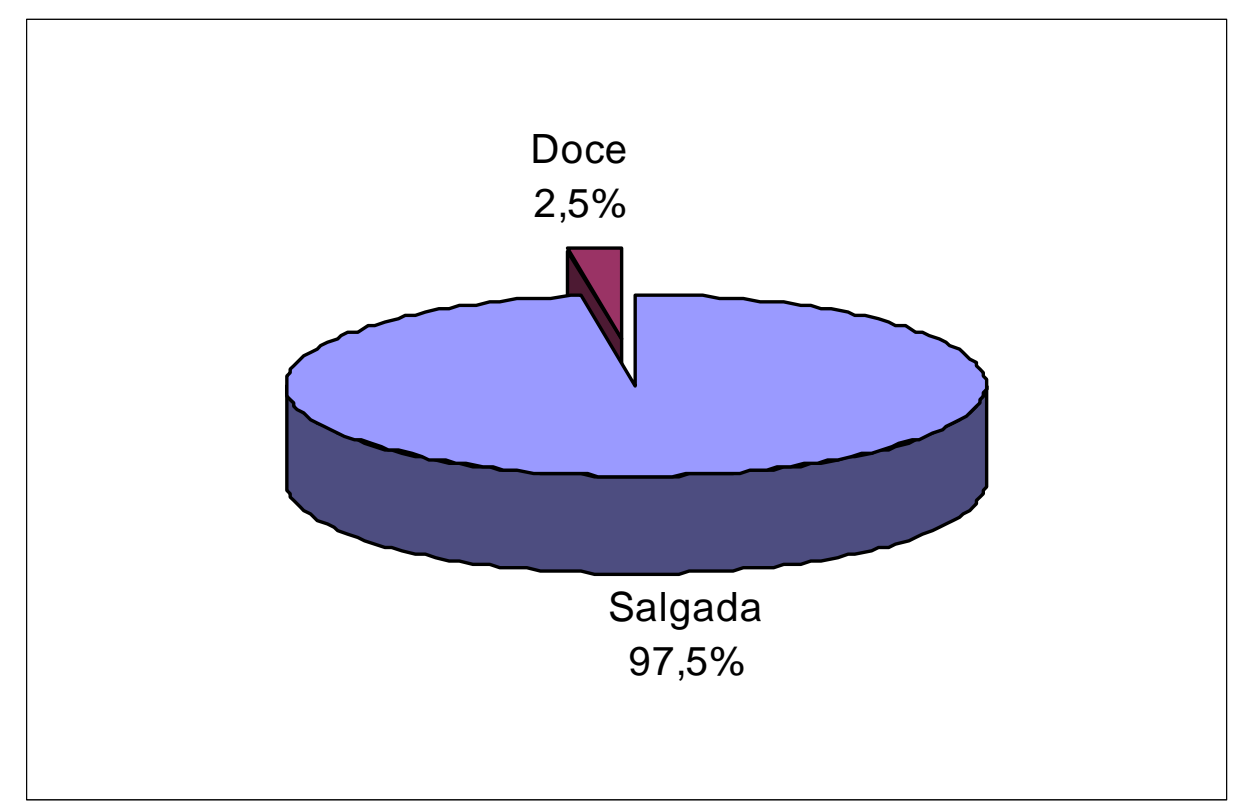


FIGURA 6 - DISTRIBUIÇÃO DA ÁGUA DOCE NA TERRA

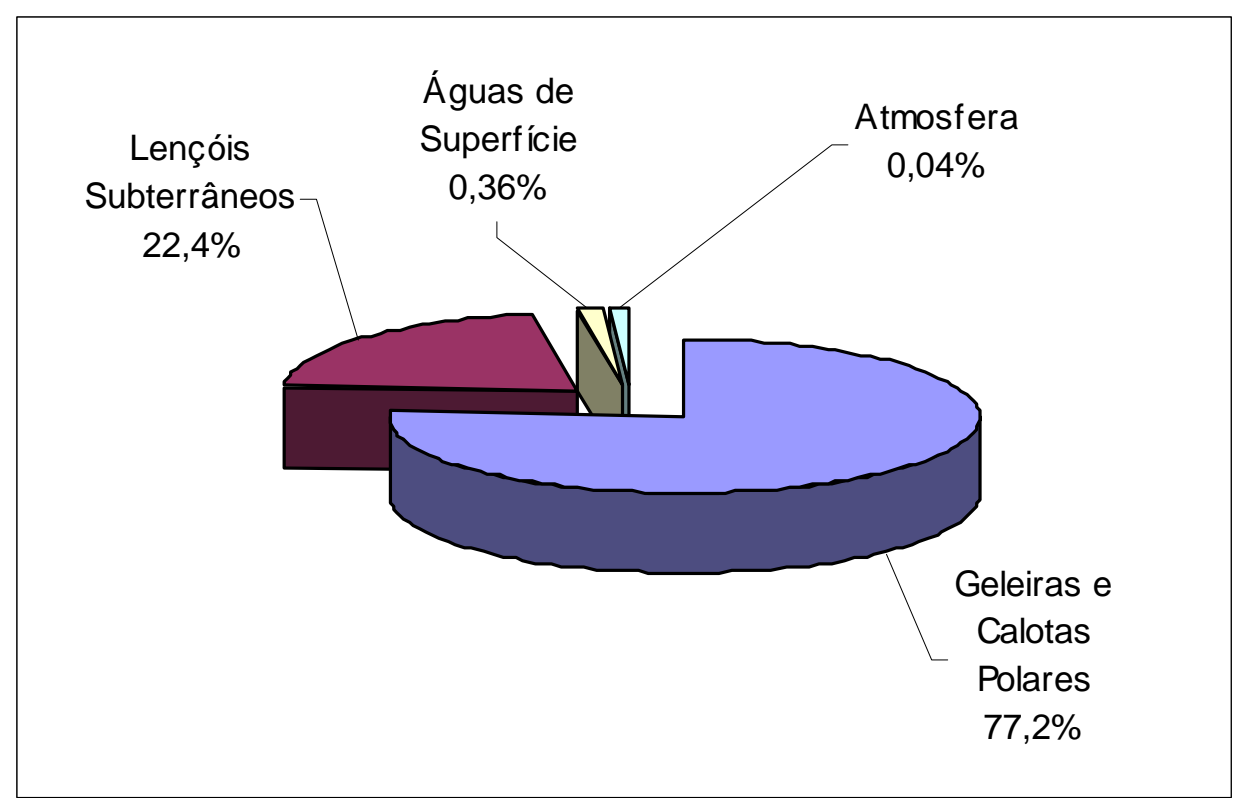

Apesar dos múltiplos usos da água, pode-se considerar que o seu consumo esteja distribuído basicamente entre a irrigação para agricultura, a indústria e o uso humano. O primeiro, na média mundial, é o que mais consome água natural ou água doce, em torno de $70 \%$ do total - aproximadamente 1.400 milhões $\mathrm{m}^{3} / a n o$. Nos Estados Unidos e na Europa, o maior consumo é feito pelas indústrias. Segundo o Programa das Nações Unidas para o Ambiente (UNEP) (2000, apud Aegisson, 2002, pág. 01) e a Revista Isto É (1695/2002, pág. 87), o consumo humano é o que mais tem causado preocupação, uma vez que do ano de 1900 até o ano de 1995 aumentou em 6 vezes - maior que o dobro da taxa de crescimento da população.

Segundo este último artigo, no ano de 2002, mais de um bilhão de pessoas já estavam privadas do acesso à água potável e quase três bilhões não possuíam serviços de saneamento. Somente no Brasil, eram 70 milhões sem água para qualquer necessidade, nem mesmo para aquelas consideradas básicas, e além dessas pessoas, ainda existiam 87 milhões sem esgotamento sanitário. Estimou- 
se na mesma época que até o ano de 2050, o número de pessoas sem água, quintuplicaria.

Até pouco tempo, os recursos hídricos eram considerados renováveis. Entretanto, a condição para sua reposição natural está cada vez mais difícil. Atualmente, a possibilidade de renovação da água depende da continuidade do ciclo hidrológico e da gestão correta para a sua constante disponibilidade. O ciclo hidrológico é o processo de reposição da água na Terra que tem início quando as águas do mar e dos continentes se evaporam, formam nuvens e voltam a cair na terra sob a forma de chuva, neblina e neve. Depois escorrem para rios, lagos ou para o subsolo formando os importantes aqüíferos subterrâneos ou lençóis freáticos, e aos poucos, correm de novo para o mar mantendo o equilíbrio no sistema hidrológico do planeta. É importante ressaltar que as nuvens formadas pela evaporação de águas contaminadas por dejetos industriais (e residenciais) e esgoto sem tratamento resultam na formação de chuva ácida. Portanto, a qualidade das águas que retornam ao solo e subsolo depende do tratamento correto do esgoto industrial e residencial para garantir a disponibilização de água adequada ao consumo.

A capacidade de renovação da água tornou-se lenta e difícil, fazendo deste recurso - até o momento - finito, resultado de um crescimento populacional acelerado, da contaminação (e poluição) dos rios pelos efluentes industriais (e também residenciais) e defensivos agrícolas, e do elevado desperdício da sociedade ao longo dos anos. De acordo com a Revista Isto É (1695/2002, pág. 86) estes fatores foram - e ainda são - os responsáveis por este recurso ter se tornado tão precioso e estratégico, tanto quanto o ouro e o petróleo. Tais ações desencadearam mudanças no clima global que poderão refletir na disponibilização e distribuição de água para o consumo, no que se refere tanto à sua qualidade quanto à sua quantidade. Portanto, deve ser bem gerenciada como recurso para que esteja sempre disponível em condições adequadas para o seu uso. 
Além de ser essencial para a sobrevivência, ela também é fator determinante quanto à riqueza de um país, razão pela qual compreende-se o seu alto consumo na agricultura bem como a sua necessidade para a geração de energia elétrica. A expansão dos centros urbanos e crescimento da economia são conseqüências de grandes ações que utilizam a água para a sua realização e nas quais sua presença é insubstituível.

Porém, a concepção equivocada de que a água é apenas um bem de consumo, uma mera mercadoria, levou governos, indústrias (grandes consumidores) e a própria população a ignorarem este recurso vivo. O desperdício, a retirada inadequada e descontrolada, a distribuição desigual da água, seja devido às características físicas da própria região ou não, o lançamento de lixo, esgoto e produtos químicos nos rios, córregos e em outras formas de abastecimento, e as práticas de utilização do solo - desmatamento, utilização de agrotóxicos em plantações, a expansão urbana, a deposição inadequada de dejetos - causaram uma depreciação na qualidade e quantidade dos recursos hídricos brasileiros. Essa situação é compreendida pelo racionamento e falta d'água, dentre outros, que tem acontecido em diferentes municípios no Brasil e em várias partes do mundo. A escassez do recurso tem estimulado cada vez mais a competição entre seus usuários, ultrapassando a capacidade das instituições responsáveis de administrar o problema.

Contudo, várias outras questões como o desvio e represamento fluvial, a salinização e encharcamento do solo, resultam de um sistema de irrigação inadequado, contaminando os aqüíferos, dentre várias outras conseqüências. Ao final, percebe-se que todo o mau uso da água na realização de atividades econômicas e lucrativas ou mesmo quando estas são realizadas sem um conhecimento fundamentado sobre as suas conseqüências no solo e na própria característica da água, acaba resultando alterações na composição deste recurso de forma depreciativa, o que impossibilita sua (re) utilização sem riscos. 
Consoante as organizações UICN, PNUMA, WWF (1991, pág. 149), para mudança desse quadro atual,

As sociedades humanas precisam desenvolver a habilidade conscientização, conhecimento, procedimentos e instituições - para administrar seu uso da terra, como também da água, de uma forma integrada e abrangente, de modo a manter a qualidade e a quantidade do suprimento de água para as pessoas e para os ecossistemas que as suportam.

De acordo com os mesmos órgãos, a falta dessa habilidade é uma questão central a ser tratada por uma estratégia para alcance da sustentabilidade. O uso sustentável dos recursos hídricos depende fundamentalmente do conhecimento e adaptação das pessoas ao ciclo hidrológico, e não o contrário, onde a água tenha que estar sempre disponível à população e seu crescimento.

\subsection{Gerenciamento: instituição x indivíduo}

Para compreender a gestão das águas no Brasil, é necessário entender primeiramente o que é a bacia hidrográfica e a sua função na gestão, pois trata-se da delimitação territorial utilizada como unidade de planejamento, integrando políticas para a implementação de ações conjuntas visando o uso, a conservação e a recuperação das águas.

Segundo a Secretaria de Recursos Hídricos (2003, pág. 13), bacia hidrográfica é 
(...) uma área da superfície terrestre, delimitada pelos pontos mais altos do relevo, na qual a água proveniente das chuvas escorre para os pontos mais baixos do relevo, formando um curso de água (rio) ou lago. É como o piso que recolhe toda a água que cai em um determinado local e a encaminha para as partes mais baixas (ralo).

Esta delimitação - de bacia hidrográfica - pode ser diferente da divisão administrativa, ocasionando algumas vezes a integração das políticas públicas e regionais de um ou mais municípios e estados.

Brasil possui situação privilegiada em relação aos demais países quanto à sua disponibilidade hídrica, porém a sua distribuição nas regiões é bastante diferenciada. Os problemas nacionais de escassez hídrica decorrem, principalmente, da combinação entre o crescimento exagerado das demandas localizadas (principalmente nos grandes centros) e da degradação da qualidade das águas. Essa situação é conseqüência dos processos desordenados de urbanização, industrialização e expansão agrícola.

A distribuição dos recursos e população por região pode ser visualizada no quadro abaixo (MME e SRH, 2003, pág. 16). Com a grande concentração dos centros urbanos não apenas o fornecimento de água deixa a desejar, se o gerenciamento de água por parte dos órgãos responsáveis e também pela sociedade não for bem conduzido, o esgotamento sanitário e as condições do solo do entorno ficam prejudicados. Além disso, o uso da água se não adequado, ou seja, sem tratamento, pode também ser meio de transmissão de muitas doenças, tais como: esquistossomose, disenteria por amebas, leptospirose, cólera, febre tifóide, hepatite viral, poliomielite, ancilostomose (amarelão), dengue, entre outras. 


\section{FIGURA 7 - DISTRIBUIÇÃO DA ÁGUA, DA SUPERFÍCIE E DA POPULAÇÃO (em \% do total do País)}

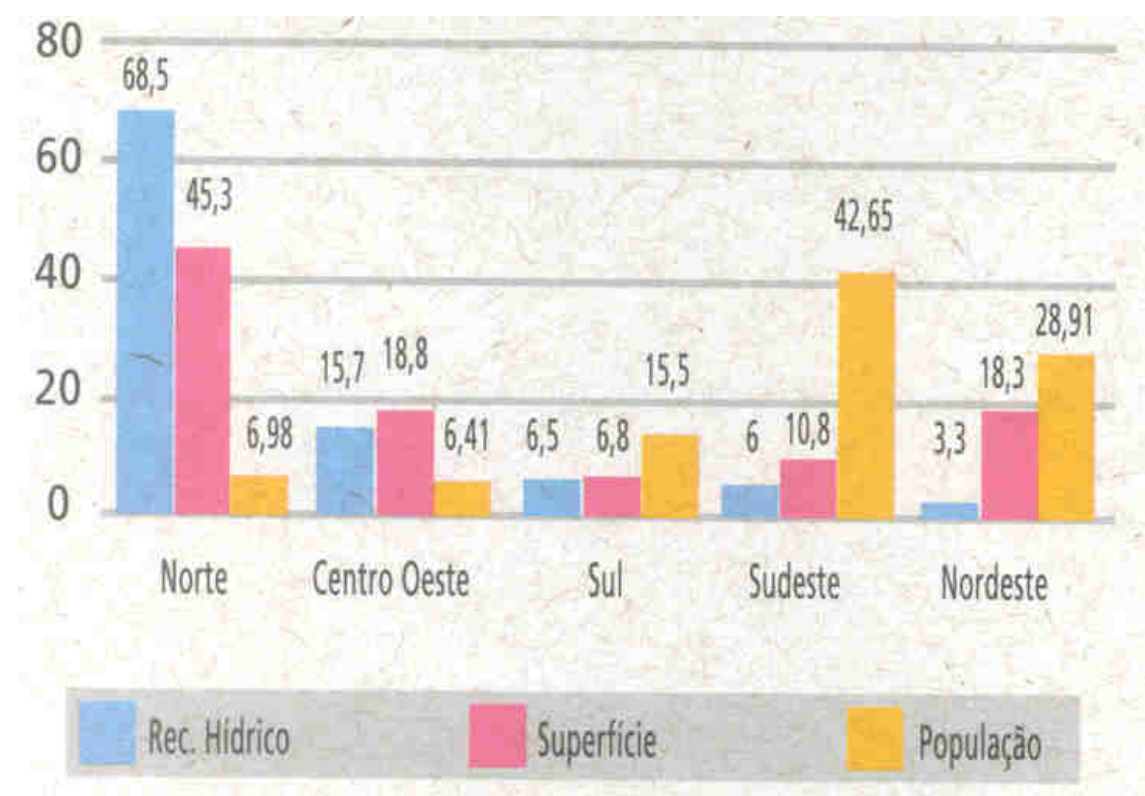

FONTE: MMA e SRH, 2003, pág. 16

Como já exposto, a crise em torno da água exige mudanças pessoais de uso da mesma. Esta crise "reflete a crise de consciência da nossa civilização e do modelo de 'desenvolvimento' mundial atual, desigual, excludente e esgotante dos recursos naturais" (Secretaria de Recursos Hídrico, 2003). Para reverter o quadro de degradação ambiental e desigualdades sociais é necessário buscar um novo modelo de desenvolvimento e também a sua sustentabilidade. Entretanto, para isso seja possível deve-se conhecer conceitos, leis, organismos, estruturas e os instrumentos de gestão de recursos hídricos.

A gestão dos recursos hídricos no Brasil está baseada na Constituição Federal, de 1988, na Lei Federal No 9.433, de 08/01/1997, na Lei Federal № 9.984, de 17/07/2000, nas Constituições Estaduais, de 1989 e nas Leis Estaduais (criadas a partir de 1991). 
A Lei 9.433, de 8 de janeiro de 1997, que instituiu a Política Nacional de Recursos Hídricos (PNRH) e o Sistema Nacional de Gerenciamento dos Recursos Hídricos (SNGREH), considera os seguintes fundamentos:

- a água é um bem público;

- a água é um recurso natural limitado, dotado de valor econômico;

- em situações de escassez, a prioridade é o consumo humano e a dessedentação de animais;

- a gestão dos recursos hídricos deve proporcionar o uso múltiplo;

- a bacia hidrográfica é a unidade territorial de implementação da Política e de atuação do Sistema;

- a gestão dos recursos hídricos deve ser descentralizada e contar com a participação do Poder Público, dos usuários e das comunidades.

POLÍTICA NACIONAL DE RECURSOS HÍDRICOS

A PNRH visa assegurar à atual e às futuras gerações a necessária disponibilidade de água, em padrões de qualidade adequados aos respectivos usos; a utilização racional e integrada dos recursos hídricos, incluindo o transporte aqüaviário, com vistas ao desenvolvimento sustentável; a prevenção e a defesa contra eventos críticos, de origem natural ou condicionados pelo ser humano, decorrentes do mau uso dos recursos hídricos.

Para o alcance dos objetivos citados, a PNRH tem como diretrizes a gestão sistemática dos recursos hídricos, sem dissociação dos aspectos de quantidade e qualidade; a adequação da gestão de recursos hídricos às diversidades das diversas regiões do País; a integração da gestão dos recursos hídricos com a gestão ambiental; a articulação do planejamento de recursos hídricos com o dos setores usuários e com planejamento regional, estadual e nacional; a articulação 
da gestão dos recursos hídricos com a do uso do solo e a integração da gestão das bacias hidrográficas com a dos sistemas estuarinos e costeiros.

Os instrumentos utilizados pela Política Nacional de Recursos Hídricos em suas ações são:

- os Planos de Recursos Hídricos;

- o enquadramento dos corpos de águas em classes de usos preponderantes;

- a outorga de direitos de uso dos recursos hídricos;

- a cobrança pelo uso dos recursos hídricos;

- a compensação aos Municípios;

- o Sistema de Informações sobre Recursos Hídricos.

SISTEMA NACIONAL DE GERENCIAMENTO DE RECURSOS HÍDRICOS (SINGREH)

Os objetivos do Sistema Nacional de Gerenciamento de Recursos Hídricos são:

- coordenar a gestão integrada das águas;

- arbitrar os conflitos relacionados com recursos hídricos;

- implementar a Política Nacional de Recursos Hídricos;

- planejar, regular e controlar o uso, preservação e recuperação dos recursos hídricos;

- promover a cobrança pelo uso dos recursos hídricos.

O Sistema é formado pelo Conselho Nacional de Recursos Hídricos (CNRH), Agência Nacional de Águas (ANA), Conselhos de Recursos Hídricos dos Estados 
e do Distrito Federal, Comitês de Bacias Hidrográficas, Órgãos Gestores federais, estaduais e municipais, Secretaria de Recursos Hídricos ( $\mathrm{SRH}$ ) e Agências de Água (ou de Bacia).

O planejamento adequado e a gestão eficiente e eficaz dos recursos hídricos devem levar em consideração o desenvolvimento sustentável, os conflitos de uso e sua conseqüente escassez, os problemas de desequilíbrio na relação disponibilidade de recurso $x$ demanda, o controle de valores negativos das águas, o aproveitamento de oportunidades para promover um maior desenvolvimento sócio-econômico e a melhoria da qualidade de vida, apoiado no seu uso múltiplo e integrado.

Além disso, uma alternativa para ajudar na descentralização das decisões referentes à forma de uso dos recursos hídricos é a criação dos comitês de bacias hidrográficas, formados por pessoas de esferas diversas da sociedade e pela própria comunidade. A participação das comunidades nessas questões possibilita que as mesmas entendam como é o processo de reposição das águas, o que pode servir como ação de mediar conflitos, já que os interesses em discussão pertencem à comunidade, visando melhorias para todos. Permitem que a comunidade adquira maior conhecimento sobre a importância da água para a manutenção das relações e processos essenciais à vida, compreendendo a importância de sua preservação. Estas novas experiências tornam-se essenciais para uma nova consciência, novas atitudes e condutas, para resultar na valorização dos recursos hídricos. 
FIGURA 8 - GERENCIAMENTO DA ÁGUA

\section{A NECESSIDADE DO GERENCIAMENTO}

A água foi formalmente considerada um BEM ECONÔMICO na Conferência Internacional sobre a Água e o Meio Ambiente, ocorrida em janeiro de 1992, em Dublin, Irlanda, bem como no capitulo 18 da Agenda 21. Considerando que a água é um BEM MINERAL e que, em certas condiçōes da natureza, ela é um BEM ENERGÉTICO (potenciais hidráulicos), a gestão desse BEM COMUM, SOCIAL e ESTRATÉGICO, indispensável à vida, deve ser tratada pelo governo e sociedade com a mais alta prioridade. $\mathrm{O}$ uso múltiplo e integrado das águas, bem como a minimização dos impactos

ambientais decorrentes, é um objetivo que deve ser constantemente perseguido.

Toda a problemática até agora descrita necessita ser encarada de maneira científica e objetiva, de modo que as complexas questōes existentes e emergentes possam ser equacionadas de forma racional. Há que se pôr em prática instrumentos que venham auxiliar gerentes e estudiosos da matéria nos processos de organização de estratégias, hierarquização e montagem de programas, bem como nos processos decisórios.

FONTE: Coimbra, Rocha e Beekman (1999, pág. 20 e 21)

Segundo o Ministério da Educação (MEC) e Secretaria de Recursos Hídricos (SRH) de (2003, pág. 10), "cuidar da água é uma questão de sobrevivência; depende da decisão e da ação de cada pessoa, comunidade e da sociedade em geral". Mas depende também do Poder Público, principalmente daqueles órgãos que são os responsáveis pela manutenção da sua qualidade, abastecimento, saneamento, fiscalização. Enfim, daqueles que a tornam disponível para o uso de todos. "Somente com sensibilidade, criatividade, determinação e participação, 
será possível construir as respostas técnicas, científicas, ecológicas, sociais, políticas e econômicas para a gestão da água na perspectiva do desenvolvimento sustentável, com inclusão social e justiça ambiental".

\subsection{A água como atrativo turístico}

A água faz parte da maioria das paisagens naturais, seja na forma de cachoeira, cascata, rios, gruta, lagoa, mar e aquário natural. São as paisagens naturais os primeiros chamarizes do ecoturismo, assim como dos demais segmentos da atividade turística desenvolvidos no meio natural.

A atividade ecoturística e seus serviços podem ser realizados de diversas maneiras e em ambientes variados, podendo ocorrer a partir do contato direto ou indireto com a água como é o caso de atrativos em que se faz apenas a contemplação.

É praticamente impossível que roteiros no meio natural não apresente em seus itinerários uma "parada rápida" sequer em alguma cachoeira, ou "apenas um mergulho" em algum rio ou poço localizado no percurso da trilha que é percorrida ao longo do percurso ou para se chegar ao atrativo final.

Uma vez que a água, bem como os demais recursos naturais, é utilizada em suas diferentes paisagens como atrativo ou como um instrumento facilitador das suas atividades e serviços, o ecoturismo deve protegê-la do uso inadequado e da intensa utilização. Se já é necessário realizar estudos de impacto ambiental, viabilidade, capacidade de carga e monitoramentos para a realização de qualquer atividade turística, é ainda mais imprescindível que as atividades ecoturísticas, quando os atrativos disponibilizados à visitação se tratarem de recursos hídricos, tenham em seu planejamento medidas que verifiquem freqüentemente a sua 
qualidade. Essa preocupação ocorre pelo fato de que a água, como já dito anteriormente, precisa ter suas características preservadas para manter as relações e processos sistêmicos, bem como a interação entre eles. Essas características são referentes à sua qualidade, quantidade e também à autenticidade. Muitas vezes uma paisagem do meio ambiente é consagrada e descrita como de beleza singular por apresentar algo que as demais não possuem, ou já não possuem, e para que seja mantida dessa forma, recorre-se à sua preservação.

A preservação do bem natural tem, na verdade, função dupla, pois preservase a cachoeira, o aquário natural, o balneário, por exemplo, como bens do patrimônio natural e também preserva-se o recurso "água". E esta função do ecoturismo é entendida pelos seus praticantes, pois o que eles buscam do contato com a natureza e seus bens (recursos) é uma nova experiência pessoal, de aprendizado; uma relação saudável e pacífica, e que tem resultados de grande valor.

Assim, a água como atrativo turístico pode ser considerada também como uma preservação a mais, desde que, tenha a sua visitação e uso controlados, e para isso os profissionais da atividade devem estar conscientes das suas responsabilidade, tanto no que diz respeito à preservação do patrimônio natural e dos atrativos, por suas ações, quanto no que se refere à conscientização do público - por meio da interpretação e educação ambiental - da fragilidade do meio ambiente e da necessidade de respeitá-lo e conservá-lo. 


\section{EDUCAÇÃO AMBIENTAL: ORIGEM, EVOLUÇÃO, PRINCÍPIOS E OBJETIVOS}

Segundo a Secretaria do Meio Ambiente de São Paulo (1997), desde o primeiro momento em que os seres humanos começaram a interagir com o seu entorno e a transmitir aos seus filhos essa interação, estava havendo educação e educação ambiental. Os povos nativos (comunidades tradicionais e autóctones, e principalmente os povos indígenas) desenvolveram uma percepção e um conhecimento sofisticados sobre os sistemas naturais que os rodeiam e um profundo respeito por eles, passando esse conhecimento e respeito de geração em geração.

Inicialmente, a relação do ser humano com a natureza estava ligada básica e essencialmente à questão da sobrevivência. "Tratava-se de uma relação que dizia respeito de como viver num mundo cuja natureza era externa e mais poderosa do que os homens, que os afetava mais do que era afetada por eles" (Secretaria do Meio Ambiente, 1997). Todos precisavam conhecer o meio ambiente para saber o que poderiam utilizar para suprir suas necessidades. Era necessário também conhecê-lo para proteger-se contra os fenômenos da natureza e para o aproveitamento das suas riquezas. Entretanto, a relação e interação da humanidade com a natureza ultrapassaram a razão única de sobrevivência, tendo a sua utilização ampliada, na qual ela também se mostrou como fonte de valores internos, tais como beleza, inspiração, identidade, significado e status pessoal, pelos quais se quer lutar.

Com a urbanização e evolução da humanidade, a percepção do ambiente mudou drasticamente e com isso a sua relação com a natureza. Esta começou somente a servir à humanidade, de acordo com suas necessidades; depois foi estudada para que a sua dominação e exploração fossem possíveis. Aquilo que se considerava inútil era estudado apenas por motivos de curiosidade. Já o 
estudo do meio ambiente, conforme a mesma Secretaria, tornou-se uma ciência prática de extração de recursos, ou ainda "um estudo do mundo natural" catálogo e descrições das maravilhas naturais. As duas definições consideravam a natureza como algo separado e inferior à sociedade humana, mas com o tempo, as constantes descobertas da ciência foram mudando essa concepção errônea sobre a natureza, construindo um sentimento de admiração do homem por ela.

Entretanto, problemas ambientais de alto grau em todo o mundo já alertavam sobre o estado de ameaça em que a natureza se encontrava. A natureza passou a ser vista como algo afetado desastrosamente pela sociedade humana que, por sua vez, tornou-se a agressora do ambiente e sua própria vítima. Com isso, o conhecimento tornou-se necessário para proteger a natureza e corrigir os erros ecológicos cometidos pelo o homem.

O livro da bióloga Rachel Carson, Primavera Silenciosa, publicado em 1962, reunia uma séria de narrativas sobre os problemas ambientais que ultrapassavam as fronteiras nacionais. Eles eram o resultado do desarranjo de processos ambientais regionais ou mesmo globais, devido a enormes impactos causados pela sociedade humana, promovidos principalmente pelo modelo de desenvolvimento econômico então adotado. Mostravam que a vida humana depende de processos naturais complexos, interconectados, de larga escala, os quais não podem absorver uma quantidade ilimitada de abusos.

Esta publicação tornou-se um trabalho-denúncia de enorme relevância pois alertou a sociedade mundial sobre a temática ambiental, que passou a fazer parte das inquietações políticas internacionais, fazendo com que os movimentos ambientalistas surgissem de maneira ativa, resultando no acontecimento de eventos. 
De tantos encontros promovidos, a Conferência de Estocolmo - Conferência das Nações Unidas sobre o Ambiente Humano, realizada pela ONU, em 1972, tornou-se um marco referencial para a busca de soluções dos problemas ambientais. Neste encontro, segundo Freire (1996, pág. 11), ficou decidido que seriam necessárias mudanças profundas nos modelos de desenvolvimento, nos hábitos e comportamentos dos indivíduos e da sociedade, o que só poderia ser atingido através da educação.

Entretanto, conforme o mesmo autor, reconheceu-se que a educação vigente na época não conseguiria promover as mudanças necessárias, surgindo, a partir daí, uma proposta de um novo processo educacional para executar tal tarefa: a Educação Ambiental. Devido a esta realidade, encontros de âmbito subregional, regional, nacional e internacional foram realizados para tentar definir as bases conceituais desse novo modelo de educação, os quais geraram documentos e recomendações a serem considerados.

De acordo com a Primeira Conferência Intergovernamental sobre Educação Ambiental - Conferência de Tbilisi:

a) as finalidades da E.A. são:

- Promover a compreensão da existência e da importância da interdependência econômica, social, política e ecológica;

- Proporcionar, a todas as pessoas, a possibilidade de adquirir os conhecimentos, o sentido dos valores, o interesse ativo e as atitudes necessárias para proteger e melhorar o meio ambiente;

- Induzir novas formas de conduta nos indivíduos e na sociedade, a respeito do meio ambiente.

b) as categorias de objetivos da E.A. (apud Freire, 1997, pág. 22) são: 
1. Consciência - (...) ajudar os indivíduos e grupos sociais a sensibilizarem-se e a adquirirem consciência do meio ambiente global e suas questões;

2. Conhecimento - (...) a adquirirem diversidade de experiência e compreensão fundamental sobre o meio ambiente e seus problemas;

3. Comportamento - (...) a comprometerem-se com uma série de valores, e a sentirem interesse pelo meio ambiente, e participarem da proteção e melhoria do meio ambiente;

4. Habilidades - (...) adquirirem as habilidades necessárias para identificar e resolver problemas ambientais;

5. Participação - (...) proporcionar a possibilidade de participarem ativamente das tarefas que têm por objetivo resolver os problemas ambientais.

Esses objetivos estão interligados: todos podem levar a todos. Segue abaixo, figura (Diagrama de Cooper) mostrando a inter-relação e integração desses elementos. 


\section{FIGURA 9 - OBJETIVOS DA EDUCAÇÃO AMBIENTAL}

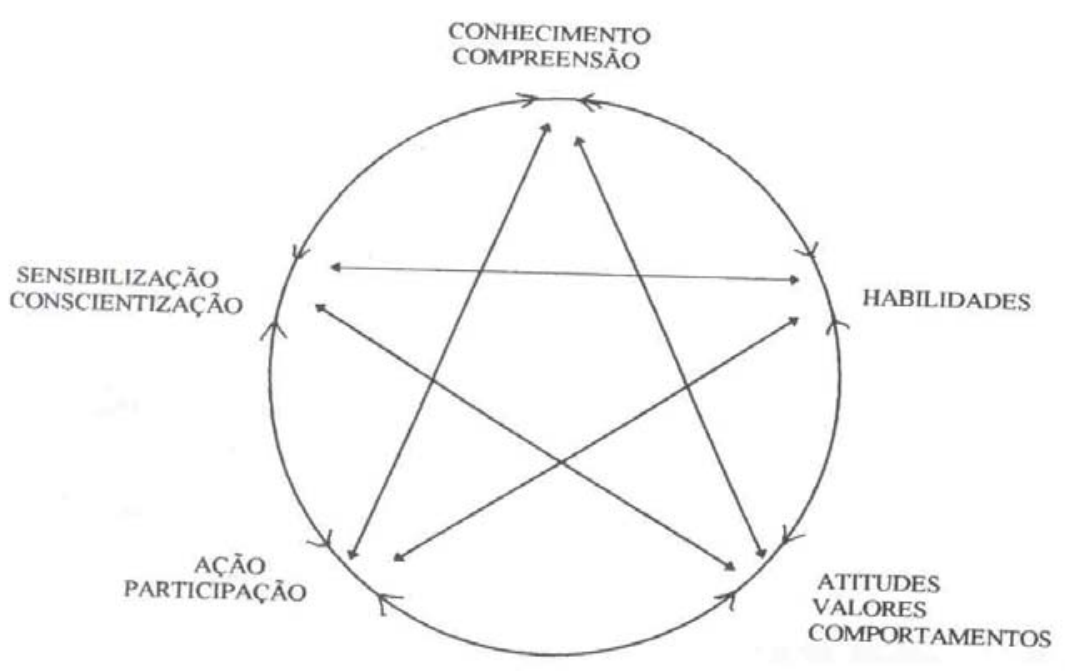

Fonte: Dias, 1997, pg. 52.

c) os princípios básicos da E.A. são:

1. Considerar o meio ambiente em sua totalidade, isto é, em seus aspectos naturais e criados pelo homem (político, social, econômico, científico-tecnológico, histórico-cultural, moral e estético);

2. Constituir um processo contínuo e permanente, através de todas as fases do ensino formal e não-formal, que podem ser compreendidas como:

- Formal $^{2}$ : processo institucionalizado que pode ocorrer nas unidades de ensino de maneira interdisciplinar com as demais ciências, cursos de capacitação, especialização e a partir de documentos formais;

\footnotetext{
${ }^{2}$ A educação ambiental, quando transmitida e trabalhada com os indivíduos mais jovens, na forma acadêmica, pode tornar-se indissociável ou, no mínimo, duradoura, dada a formação de caráter e valores das pessoas ocorrer basicamente nesta fase da vida.
} 
- Informal: realizada fora da escola, envolvendo flexibilidade de métodos e de conteúdos e um público alvo muito variável em suas características (faixa etária, nível de escolaridade, nível de conhecimento da problemática ambiental, etc.). Alguns exemplos são: os parques, zoológicos, jardins botânicos, revistas, jornais, televisão, e mesmo através das influências.

1. Aplicar um enfoque interdisciplinar, aproveitando o conteúdo específico de cada disciplina, de modo que se adquira uma perspectiva global e equilibrada;

2. Examinar as principais questões ambientais, do ponto de vista local, regional, nacional e internacional, de modo que os educandos se identifiquem com as condições ambientais de outras regiões geográficas;

3. Concentrar-se nas condições ambientais atuais, tendo em conta também a perspectiva histórica;

4. Insistir no valor e na necessidade da cooperação local, nacional e internacional, para prevenir e resolver os problemas ambientais;

5. Considerar, de maneira explícita, os aspectos ambientais nos planos de desenvolvimento e crescimento;

6. Ajudar a descobrir os sintomas e as causas reais dos problemas ambientais;

7. Destacar a complexidade dos problemas ambientais e, em conseqüência, a necessidade de desenvolver o senso crítico e as habilidades necessárias para resolver tais problemas;

8. Utilizar diversos ambientes educativos e uma ampla gama de métodos para comunicar e adquirir conhecimentos sobre o meio 
ambiente, acentuando devidamente as atividades práticas e as experiências pessoais.

A educação ambiental objetiva contribuir para a compreensão da complexidade do ambiente em suas dimensões ecológicas, econômicas, sociais, culturais, políticas, éticas e tecnológicas, de maneira a sensibilizar a coletividade quanto à importância de sua organização e participação na defesa de todas as formas de vida. Pretende-se, assim, incentivar a mobilização dos cidadãos a partir do reconhecimento das causas e das conseqüências dos impactos socioambientais que afligem o planeta, buscando satisfazer as necessidades fundamentais da humanidade ao mesmo tempo em que são respeitados os direitos das gerações futuras terem acesso a um ambiente saudável.

Constitui-se numa forma abrangente de educação, que visa atingir todos os cidadãos, através de um processo pedagógico participativo permanente que procura incutir no educando uma consciência crítica sobre a problemática ambiental, compreendendo-se como crítica a capacidade de captar a origem e a evolução de problemas ambientais.

A Carta de Belgrado (1975) define que a meta da educação ambiental é:

Desenvolver um cidadão consciente do ambiente total preocupado com os problemas associados a esse ambiente e que tenha o conhecimento, as atitudes, motivações, envolvimento e habilidades para trabalhar individual e coletivamente em busca de soluções para resolver os problemas atuais e prevenir os futuros.

Consoante a Empresa Brasileira de Pesquisa Agropecuária (EMBRAPA) (2004), a educação ambiental é reconhecida como um instrumento pelo qual "o indivíduo e a coletividade constroem valores sociais, conhecimentos, habilidades, 
atitudes e competências voltadas para a conservação do meio ambiente, bem de uso comum do povo, essencial à qualidade de vida e sua sustentabilidade".

PRINCÍPIOS DA EDUCAÇÃO AMBIENTAL PARA SOCIEDADES SUSTENTÁVEIS E PARA RESPONSABILIDADE GLOBAL

Grupos e países mais ricos vivem de forma não-sustentável por ignorância, falta de preocupação com o assunto, ou pelo incentivo ao consumismo em excesso. Para eles, em especial, a urgência é pela mudança de atitudes e práticas. Mudanças no sentido de não apenas aprenderem a utilizar os seus recursos de maneira mais sustentável, como também no sentido de que estas mudanças possam ser refletidas na economia, comércio e política, devido às alterações da visão e dos objetivos humanos.

Pessoas que têm essa característica consumista precisam ser persuadidas a mudar o seu estilo de vida, e para tanto, precisam de ajuda. Mudanças como esta podem, e geralmente, assim acontece, conflitar com valores assimilados desde 0 começo da vida e em ambientes que os estimulem a serem continuados. E para a concretização desta mudança a educação se fará insubstituível, sobretudo a educação ambiental.

Embora o consumismo destrutivo tenha muitos adeptos (que muitas vezes nem sabem que os são e que o estimulam), pesquisas têm demonstrado que a sociedade mundial já possui um certo conhecimento sobre a necessidade da conscientização ambiental para se ter perspectivas de melhorias no meio ambiente. Entretanto é certo também que as pessoas que entendem a necessidade de se viver diferentemente, de maneira mais sustentável, não conseguem seguir constantemente os seus ideais. 
De acordo com a UICN, PNUMA e WWF (1991, pág.56), a ética de uma vida sustentável somente será adotada pelas pessoas quando estas forem convencidas de que é correto e necessário fazê-lo para promover mudanças quando tiverem incentivos suficientes e puderem dispor de conhecimento e habilidades necessários.

Há a necessidade de se construir uma nova forma de compreensão das relações humanas com a natureza, através da educação formal e também do aproveitamento do poder da educação e da comunicação informais. Hoje a educação formal já tem a questão ambiental inserida na sua estrutura metodológica de forma interdisciplinar com as demais ciências, apesar de tal iniciativa ainda não ser generalizada, por falta de incentivos e de capacitação.

A educação ambiental está diretamente ligada à educação social; enquanto a primeira ajuda as pessoas a entender o meio natural e a viver em harmonia com ele, a segunda transmite o entendimento do comportamento humano e uma análise da diversidade cultural (UICN, PNUMA e WWF, 1991, pág.57).

Consoante estas mesmas Organizações, a modificação das práticas e atitudes das pessoas requer uma campanha conjunta de informação pública, incentivada pelos governos e conduzida pelas Organizações NãoGovernamentais (ONG's). Para tanto, estabelecem algumas ações prioritárias (op.cit.):

- Assegurar que as estratégias nacionais pela sustentabilidade incluam providências para motivar, educar e dar condições às pessoas para que vivam de forma sustentável;

- Rever a situação da educação ambiental e torná-la parte integrante da educação formal, em todos os níveis;

- Determinar as necessidades de treinamento para uma sociedade sustentável e planejar a sua consecução. 
Simultaneamente à Conferência das Nações Unidas sobre o Meio Ambiente e Desenvolvimento, realizada no Rio de Janeiro, em 1992 (RIO 92) - evento de grande relevância para definição do desenvolvimento sustentável por meio da elaboração da Agenda 21 (programa internacional de ação pela reversão da contínua deterioração do sistema que sustenta a vida no planeta) -, foi realizado o Fórum Global das Organizações Não-Governamentais, contando com a participação de 15.000 profissionais atuantes na temática ambiental. Nesse evento foram ratificados 32 tratados, dentre eles o Tratado de Educação Ambiental para Sociedades Sustentáveis e Responsabilidade Global, documento que constitui marco referencial da E.A., no qual são definidos os seus princípios de compromisso com mudanças nas dimensões individuais e estruturais.

O Tratado aborda os direitos e os deveres que cabem aos cidadãos, tendo em vista o estabelecimento de sociedades sustentáveis. São eles:

1. A Educação é direito de todos; somos todos aprendizes e educadores;

2. A E.A. deve ter como base o pensamento crítico e inovador (...) promovendo a transformação e a construção da sociedade;

3. A E.A. é individual e coletiva. (...) Tem o propósito de formar cidadãos com consciência local e planetária, que respeitem a autodeterminação dos povos e a soberania das nações;

4. A E.A. não é neutra, mas ideológica. É um ato político, baseado em valores para a transformação social;

5. A E.A. deve envolver uma perspectiva holística, enfocando a relação entre o ser humano, a natureza e o universo de forma interdisciplinar;

6. A E.A. deve estimular a solidariedade, a igualdade e o respeito aos direitos humanos, valendo-se de estratégias democráticas e interação entre as culturas; 
7. A E.A. deve tratar as questões globais críticas, suas causas e interrelações em uma perspectiva sistêmica, em seu contexto social e histórico;

8. A E.A. deve recuperar, reconhecer, respeitar, refletir e utilizar a história indígena e cultura locais (...);

9. A E.A. deve estimular as comunidades para que retomem a condução dos seus próprios destinos;

10. A E.A. deve valoriza as diferentes formas de conhecimento;

11. A E.A. deve ser planejada para capacitar as pessoas a trabalharem conflitos de maneira justa e humana;

12. A E.A. deve promover a cooperação e o diálogo entre os indivíduos e instituições;

13. A E.A. requer a democratização dos meios de comunicação e o seu comprometimento com todos os setores da sociedade;

14.A E.A. deve ajudar a desenvolver uma consciência ética sobre todas as formas de vida com as quais compartilhamos este planeta, respeitar seus ciclos vitais e impor limites à exploração dessas formas de vida pelos seres humanos.

Além dos documentos resultados desses importantes encontros para discussão do tema educação ambiental e meio ambiente, as campanhas desenvolvidas pelas organizações não-governamentais, poderes público e privado e sociedade são de importantíssimo valor para a conscientização das pessoas no que se refere à preservação do meio ambiente e recursos naturais, como também no que diz respeito à divulgação de informações e métodos 
educativos - muitas vezes, racionais - e explicativos quanto à forma correta de usos do mesmo.

Campanhas e ações sobre o meio ambiente são interesses de todos, independente do grupo ao qual o indivíduo pertence. Todos necessitam do meio ambiente para sobreviver, e este precisa estar em harmonia consigo mesmo, nos seus sistemas e ecossistemas, para possibilitar as relações e trocas entre eles, gerando os recursos indispensáveis às necessidades da sociedade humana e às demais, e por fim, mantendo a vida.

Esses trabalhos e projetos devem permear toda a sociedade e devem ser disponibilizados através dos meios de comunicação, seja pela mídia televisiva, impressa, eletrônica ( $C D$ Rom e Internet) e inserções nas rádios e cinemas; devem alcançar as massas populacionais de maneira geral, mas devem ser realizados a partir de uma base de conhecimento fundamentada em dados, estudos e pesquisas. Entretanto, antes disso, devem apresentar coesão e seriedade na suas formas física, estrutural e teórica em que o problema e a questão ambiental são abordados.

As campanhas e ações, independente de quem as planeja e executa, devem ter grande repercussão e aceitação pelas pessoas em geral para que novos espaços possam ser abertos para a realização de outras com objetivos de igual ou maior importância. Devem chamar a sociedade para o problema para que possa entendê-lo e ser envolvida na questão. Para isso faz-se necessário a mudança de hábitos e práticas de uso dos recursos naturais e do meio ambiente como um todo através da educação, sobretudo da educação ambiental.

Podemos citar como exemplo as campanhas realizadas pelo Ministério da Educação e do Meio Ambiente sobre noções e dicas para usar racionalmente os recursos hídricos, a energia elétrica e depósito, separação e reciclagem do lixo. Vale ressaltar os projetos e programas de E. A. desenvolvidos por esses 
ministérios e por outros órgãos como o IBAMA, EMBRAPA, e empresas privadas ou públicas, como as Centrais Elétricas do Norte do Brasil (ELETRONORTE).

Além dessas campanhas, realizadas pelos órgãos públicos, pode-se citar aquelas desenvolvidas por grupos da sociedade e ONG's que realizam programas para conscientizar a sociedade, principalmente aquelas comunidades que residem ao longo das margens e trajetos de rios, lagos dentre outros, como o Projeto Manuelzão ${ }^{3}$ e a campanha Água para a vida. Água para todos ${ }^{4}$ desenvolvida pelo WWF-Brasil (2004). O Projeto é desenvolvido pela Universidade Federal de Minas Gerais (UFMG) e parcerias e dentre muitas ações já realizadas, elaborou um documento importante para a mobilização e participação das escolas no processo de educação ambiental que desenvolve junto às comunidades residentes ao longo do Rio das Velhas (MG): a cartilha Gestão e Agenda Ambiental Escolar. Já a Campanha é desenvolvida em âmbito nacional através da mídia televisiva, da veiculação em rádios e de material impresso, e tem o intuito de alertar a todos e chamá-los para o problema da água no país, e, conseqüentemente no mundo.

As ações destes projetos são planejadas para sensibilizar toda as comunidades do entorno sobre importância da bacia hidrográfica, rios, nascentes e mananciais, como também da recuperação e preservação das matas ciliares próximas à área nas quais são desenvolvidas, mas visam também à sensibilização de toda sociedade, independentemente de serem locais; são idealizadas e planejadas da seguinte forma: pensar global, agir localmente.

Vale lembrar que existem ainda as pesquisas e trabalhos sobre 0 gerenciamento dos recursos hídricos e a importância de ser realizado de maneira correta tanto institucional como individualmente, desenvolvidos por autarquias

\footnotetext{
${ }^{3}$ Ver informações sobre o Projeto (Projeto Manuelzão, 2004) no Anexo A.

${ }^{4}$ Ver material impresso da Campanha no Anexo B.
} 
como a ANA e ANEEL que estão diretamente ligadas ao assunto "água" pela a sua administração e uso para a prestação de seus serviços e disponibilização do produto "energia elétrica".

A educação ambiental demonstra-se, portanto, indispensável para o desenvolvimento da percepção ambiental, instrumento fundamental para a conscientização e mudança de valores e atitudes. Ela visa contribuir na formação de uma sociedade sustentável, de agentes multiplicadores da percepção ambiental nos diversos setores (público, privado e sociedade civil), envolvendo-os no processo de construção coletiva do conhecimento da realidade ambiental. Trata-se de um macro processo educacional voltado à conscientização da sociedade sobre a importância do meio ambiente. 


\section{EDUCAÇÃO AMBIENTAL EM ATRATIVOS TURÍSTICOS}

A educação ambiental desenvolvida no ecoturismo dá oportunidade às pessoas de terem novos conhecimentos e percepções, conduzindo-as a novas condutas e atitudes diante do meio ambiente, resultadas das experiências pessoais com o mesmo.

Além de possibilitar essa compreensão por meio da realização do Ecoturismo, a educação ambiental na atividade propõe mudanças necessárias de atitudes e práticas diárias, corriqueiras de uso dos recursos naturais, principalmente os mais essenciais, como a água.

De acordo com a WWF (2003), os recursos hídricos do Brasil sofreram, nas últimas décadas, uma deterioração significativa (tanto em qualidade quanto em quantidade) devido à ausência de educação ambiental e de políticas adequadas para o uso dos mesmos. O desperdício, a utilização do solo e as práticas impostas a este (uso de agrotóxicos, desmatamento da mata ciliar), a distribuição desigual da água, o despejo de dejetos, lixo, e produtos químicos (industrial e de uso doméstico) nos corpos d'água e vias sem tratamento resultaram na poluição da água e na diminuição do recurso adequado ao consumo.

Esses resultados negativos da ação do ser humano quanto à gestão da água levaram-na a ser comparada ao ouro e ao petróleo em matéria de preciosidade, a ponto de hoje já ser considerada por muitos o motivo de uma possível futura guerra, o que é indesejável por todos. Para tanto, é necessária a mobilização e busca de todos por uma melhor qualidade de vida e do meio. Necessita-se da união e do empenho de todos, e não apenas de partes da sociedade mundial. 
A concepção equivocada de que a água era uma mercadoria a ser consumida de maneira descontrolada e de que a temos em abundância levou a sociedade em geral a ignorar este recurso vivo. O desperdício, a retirada inadequada e descontrolado, a distribuição desigual da água, seja devido às características físicas da própria região ou não, o lançamento de lixo, esgoto e produtos químicos nos rios, córregos e em outras formas de abastecimento, e as práticas de utilização do solo - desmatamento, utilização de agrotóxicos em plantações, expansão urbana, deposição inadequada de dejetos - causaram uma depreciação na qualidade e quantidade dos recursos hídricos brasileiros. Essa situação é compreendida pelo racionamento e falta de água, dentre outros, que tem acontecido em diferentes municípios no Brasil e em várias partes do mundo.

Visto isso, a realização de atividades educativas voltadas à conscientização ambiental e à captação e utilização sustentável dos recursos naturais, torna-se uma das mais importantes e eficazes formas de mudar esse quadro atual preocupante.

A Educação Ambiental surge, portanto, como instrumento capaz de minimizar e, muitas vezes, solucionar problemas quanto ao uso correto dos recursos naturais e que afetam o equilíbrio do meio ambiente. Essa conscientização ecológica e também social acaba por determinar e mudar o tipo de ações a serem praticadas pela sociedade, uma vez que visa a sensibilização desta sobre o que é o meio ambiente, como um todo, suas relações com outros sistemas, como é o seu funcionamento e qual é a importância desta sociedade no mesmo, já que esta encontra-se inserida nele, e não à parte, como antes se considerava.

A água como atrativo turístico revela-se um ambiente favorável ao fornecimento de informações que possam ser desconhecidas pelos visitantes e turistas, tornando-se um instrumento de conscientização da sua fragilidade e importância para a vida de todos os seres. 
O turismo em cidades que apresentam grande concentração urbana na época de alta temporada gera um alto nível de consumo da água e com isso, de poluição dos rios ou outras formas de corpos d'água. Cidades que recebem um número de turistas acima da sua capacidade de fornecimento do recurso tendem a sofrer ainda mais a escassez do mesmo. Desta forma é necessário limitar e/ou reduzir o número de turistas em tais cidades (o que na visão econômica seria inviável) e apresentar propostas que venham minimizar os impactos nos recursos hídricos e infra-estrutura locais, causados pelo aumento da atividade, acompanhadas também de informações à população e ao turista sobre a importância do uso racional destes recursos.

A realização de cursos de capacitação e encontros para divulgação de informações a respeito da água e dos demais recursos naturais locais destinados à comunidade podem ser uma alternativa para envolvê-la a fim de que esta participe das decisões e atue no processo de educação ambiental como agente multiplicador no próprio município. Isso resultaria na mobilização da comunidade por uma vida com melhores índices de qualidade, respeitando o meio ambiente e o limite da exploração dos recursos para o turismo e as demais atividades. Resultaria numa população mais consciente sobre os seus direitos e deveres para com o meio ambiente e formaria cidadãos difusores da educação ambiental entre os turistas e os visitantes.

Estas iniciativas de conscientização e mobilização já são realizadas e tem a sua boa aceitação percebida devido ao aumento do número de instituições, escolas e ONG's que organizam e realizam passeios e visitas a atrativos ecoturísticos. Estas ações têm o intuito de utilizar as informações sobre 0 ecossistema que estão, bem como sobre a sua função no meio ambiente como um todo, para repassá-las aos alunos-visitantes proporcionando-lhes ricas experiências individuais com a natureza. Passeios educativos em lugares que possibilitam este maior contato com o meio natural e por este motivo os são conhecidos, já se tornou uma opção inovadora de aprendizado, que muitas vezes são realizados através de parcerias entre escolas e ONG's. 
Um exemplo que pode ser citado é o Instituto Ambiental Vidágua ${ }^{5}$, uma "organização não-governamental, sem fins lucrativos, que tem entre seus objetivos o desenvolvimento de projetos e programas no setor ambiental, buscando a melhoria da qualidade de vida e o desenvolvimento sustentável..." (Instituto Ambiental Vidágua, 2004). Segundo o instituto, as escolas de toda a região de Bauru, independente de serem públicas ou privadas, são atendidas pelo seu Programa de Educação Ambiental, que já atendeu mais de cem mil crianças e jovens. As atividades são as mais diversas: palestras, visitas monitoradas, expedições ecológicas, além da capacitação de professores e outros interessados. Além do Programa de Educação Ambiental, o instituto tem outros programas, sendo que todos são relacionados à preservação do meio ambiente, tais como: Programa de Monitoramento Hídrico, de Recuperação de Áreas Degradadas, de Direito Ambiental, Clickarvore e, ainda, complementando, o de Voluntariado.

Apesar destas experiências serem apenas consideradas como viagens ou passeios educativos, trata-se de uma iniciação ao ecoturismo, pois as atividades a serem realizadas serão acompanhadas de monitoramento e informações educativas e sobre meio, algumas características deste segmento do turismo. Este turismo educativo, proporcionado pelas instituições interessadas na qualidade do meio ambiente e na relação do homem com o mesmo, ajuda a despertar desde cedo a consciência ecológica e também social dos seus praticantes (alunos), tornando-se uma importante ferramenta para o alcance de uma educação evoluída e fortalecida, indispensáveis para impulsionar outras melhorias nas demais necessidades básicas humanas, que ainda, no Brasil, encontram-se consideravelmente enfraquecidas.

A população dos destinos turísticos, bem como o turista e o visitante, deve ter e receber esta preparação educacional e ética para adequar-se ao tipo de turismo que se deseja nos municípios. Essa preocupação e conhecimento sobre

\footnotetext{
${ }^{5}$ Esta ONG foi fundada em 1994 e localiza-se na cidade de Bauru, SP.
} 
as relações dos vários sistemas e ecossistemas com os recursos naturais aproximarão a sociedade da natureza e poderão refazer a ligação outrora perdida. A educação ambiental permite essa conscientização e deve ser estimulada em todos os níveis sociais na tentativa de mudar o comportamento e as práticas da atual sociedade consumista - de bens industriais e de recursos naturais - para preservação do meio ambiente equilibrado e manutenção da qualidade de vida. 


\section{CONSIDERAÇÕES FINAIS}

Ao analisar a atual situação dos recursos hídricos quanto à sua disponibilidade e qualidade, verifica-se que há muito tempo a humanidade vem trabalhando contra si mesma, a favor da sua extinção e das demais espécies, dentre animais e vegetais, uma vez que sem água não existe a possibilidade de vida. A poluição e contaminação da água, a cultura do seu desperdício, a sua retirada de maneira descontrolada, a falta de saneamento básico, são alguns dos resultados das suas ações.

É certo que para mudar esta situação e até mesmo a sua reversão, embora lentamente, tem que haver a conscientização ecológica mundial. A água e os demais recursos disponíveis na natureza precisam de cuidados. Todos eles devem ser percebidos e compreendidos para então serem respeitados e terem o seu equilíbrio assegurado. O segundo não acontece sem o primeiro.

A realização de atividades junto ao meio ambiente que possibilitam experiências e aprendizados de crescimento pessoal e principalmente que resgatam a relação homem e natureza, no sentido que este a compreenda na sua forma complexa, é fundamental para uma mudança do modelo econômico e do estilo de vida atuais. Estas atividades devem ser baseadas na educação ambiental e reforçadas pela educação formal que, apesar de ter evoluído no sentido de abordar e trabalhar os valores ambientais e sociais correlacionados entre si, ainda não alcançou plenamente seus objetivos.

Como se procurou discutir ao longo deste trabalho, uma vez que o ecoturismo permite a realização de atividades educativas e reflexivas, possibilita alcançar um estágio mais elevado de consciência, de solidariedade e de conduta que poderá contribuir para a mudança ética da humanidade. Se estas práticas 
forem, além disto, aliadas a campanhas, projetos e programas que utilizem a água como instrumento multiplicador da educação e conscientização ambiental, certamente se alcançará a sustentabilidade - uma sociedade economicamente sustentável, ambientalmente correta e justa. 


\section{REFERÊNCIAS BIBLIOGRÁFICAS}

AEGISSON, Gunnar. Ponto de Vista - O Grande Furto da Água. One World Action: for a just ande qual world, 2002.

BARRETO, Margarita e TAMANINI, Elizabete (org.). Redescobrindo a ecologia no turismo. Caxias do Sul: EDUCS, 2002.

BOFF, Leonardo. Ecologia: grito da terra, grito dos pobres. Rio de Janeiro: Sextante, 2004.

. Saber cuidar: Ética do humano - compaixão pela terra. Petrópolis: Vozes, 1999.

CÓDIGO Mundial de Ética do Turismo. Organização Mundial do Turismo, 1999.

COIMBRA, Roberto, ROCHA, Ciro Loureiro e BEEKMAN, Gertjan Berndt. Recursos hídricos: conceitos, desafios e capacitação. Brasília: ANEEL, 1999.

CORREIA, José de Anchieta. Imersão no Turismo. Porto Velho: Sebrae, 2002.

CUIDANDO do planeta terra: uma estratégia para o futuro da vida. São Paulo: UICN, PNUMA, WWF, 1991.

DIAS, Genebaldo Freire. Caderno da Católica - Série Biologia: Fundamentos da Educação Ambiental. Brasília: Universa, 1997.

ELETRONORTE. Novo Norte Brasília. Brasília, 21 de junho de 2004, Ano 9, no 144, Seminário de Aprimoramento de Política Ambiental, pág. 4.

EMPRESA Brasileira de Pesquisa Agropecuária. Disponível em <http://www.embrapa.gov.br/>. Acesso em 25 jul. 2004. 
FARIA, Dóris Santos de e CARNEIRO, Kátia Saraiva. Sustentabilidade ecológica no turismo. Brasília: Editora Universidade de Brasília, 2001.

FERREIRA, Aurélio Buarque de Holanda. Miniaurélio Século XXI Escolar: $\mathbf{O}$ Minidicionário da língua portuguesa; 4. ed. rev. ampliada - Rio de Janeiro: Nova Fronteira, 2000.

INSTITUTO Ambiental Vidágua <http://www.vidagua.org.br>. Acesso em 14 set. 2004.

INSTITUTO Brasileiro de Turismo. Disponível em <http://www.embratur.gov.br/>. Acesso em 25 jul. 2004.

MINISTÉRIO da Educação e Secretaria de Educação Fundamental. Programa parâmetros em ação, meio ambiente na escola: guia do formador. Brasília: MEC e SEF, 2001.

MINISTÉRIO da Educação e Secretaria de Educação Fundamental. Programa Parâmetros em Ação, meio ambiente na escola: guia de orientação para trabalhar com vídeos. Brasília: MEC e SEF, 2001.

MINISTÉRIO do Esporte e Turismo e Instituto Brasileiro de Turismo. Programa de Iniciação Escolar para o Turismo. Turismo, Patrimônio e Cidadania: embarque nessa. Manual do Professor. Brasília: EMBRATUR, 2001.

MINISTÉRIO do Meio Ambiente e Secretaria de Recursos Hídricos. Documento de Introdução - Plano Nacional de Recursos Hídricos: iniciando um processo de debate nacional. Brasília: MMA e SRH, 2003.

MITRAUD, Sylvia (org.) Manual de Ecoturismo de Base Comunitária: ferramentas para um planejamento responsável. Brasília: WWF-Brasil, 2003.

MOLINA, Sergio e RODRÍGUEZ, Sergio. Planejamento integral do turismo: um enfoque para a América Latina. Tradução: Carlos Valero. Bauru: EDUSC, 2001. 
PIRES, Paulo dos Santos. Dimensões do Ecoturismo. São Paulo: SENAC São Paulo, 2002.

MENCONI, Darlene e MELO Liana. Diamantes pelo ralo. REVISTA Isto É. 27 de março de 2002, 1695, Seção Ciência e Tecnologia, Abastecimento, págs. 86 e 87.

SECRETARIA do Meio Ambiente e Coordenadoria de Educação Ambiental. Conceitos para se fazer educação ambiental; 2.ed. - São Paulo: Secretaria,1997. Disponível em Ambiente Brasil: http//www.ambientebrasil.com.br.

MINISTÉRIO da Educação. Disponível em $<$ http://www.educacao.gov.br/se/educacaoambiental/camtecni.shtm>. Acesso em 17 set. 2004.

PROJETO Manuelzão. Disponível em <http://www.manuelzao.ufmg.br>. Acesso em 10 jun. 2004.

WWF-BRASIL. Disponível em <http: www.wwf.org.br/projetos/agua_principal.htm>. Acesso em 18 jun. 2004. 


\section{ANEXOS}

ANEXO A - Informações sobre o Projeto Manuelzão

ANEXO B - Material impresso da Campanha Água para a vida. Água para todos. 


\section{ANEXO A}

\section{Projeto Manuelzão}

$\underline{\text { Introdução }}$

Saúde, meio ambiente e cidadania. Atualmente, estes são assuntos que têm aparecido constantemente na lista de preocupações dos mais diversos setores da nossa sociedade. Todos nós vivemos no mesmo planeta e o que acontece com ele acaba nos afetando também.

O Projeto Manuelzão surgiu com o objetivo de melhorar essa convivência do homem com o meio ambiente que o cerca, aqui, em Minas Gerais. Nasceu na $\underline{\text { UFMG, }}$ associado ao Internato Rural um programa da Faculdade de Medicina. Sua área de atuação é na bacia do Rio das Velhas, trabalhando junto à população de 51 municípios dessa região. O Projeto Manuelzão procura pesquisar e conhecer a área onde trabalha e, com a colaboração das comunidades locais, melhorar a qualidade das águas da Bacia e trazer o peixe de volta para os rios. Essa homepage está aqui para que você possa conhecer melhor a natureza do Projeto e tudo que ele tem feito. Muito prazer, esse é o Projeto Manuelzão!

\section{$\underline{\text { Objetivos }}$}

> Revitalização da Bacia Hidrográfica do Rio das Velhas, com monitoramento através de bioindicadores;

Viabilizar o desenvolvimento econômico e social sustentável na região da Bacia, melhorando a qualidade de vida da população, com saúde e cidadania; 
$>$ Promover a educação ambiental nos diversos municípios que integram a Bacia do Rio das Velhas;

> Mobilizar a população, as lideranças políticas e empresariais de toda a Bacia para solucionar os problemas ambientais, tornando a questão da sua revitalização um fator de primeira grandeza na vida do estado;

> Prover a Universidade de uma área prioritária de atuação onde possa ser desenvolvido o aprendizado no trabalho bem como pesquisas e atividades de extensão, visando o desenvolvimento acadêmico integrado dos alunos e professores;

Envolver diversos setores da universidade e sociedade com a finalidade de realizar um trabalho interdisciplinar e interinstitucional.

\section{Metodologia}

O Projeto Manuelzão abrange a Bacia do Rio das Velhas, envolvendo Belo Horizonte e diversos municípios que integram essa região, indo, grosso modo, de Ouro Preto a Pirapora. Todos os afluentes maiores ou menores do Rio das Velhas estão incluídos no projeto.

A pedagogia do aprendizado no trabalho está na base do Projeto, permitindo o desenvolvimento teórico e prático nas atividades de graduação, pesquisas e extensão desenvolvidas junto à comunidade. A idéia é que na questão ambiental todos devem envolver-se: população, instituições e técnicos. Começou com a experiência adquirida com o Internato Rural (IR) - projeto desenvolvido com alunos dos últimos anos dos cursos de medicina e odontologia junto às comunidades do interior. No trabalho comunitário, é maior o contato interpessoal e mais perceptível o quadro sócio-antropológico e político. Viu-se que a região metropolitana de Belo Horizonte é uma área de importância estratégica para a revitazlização da Bacia e o trabalho aí assume dimensões cada vez maiores. 
A preocupação com a definição das prioridades e linhas de trabalho do Projeto é grande. Os maiores agravos são os esgotos domésticos e industriais - a questão do saneamento básico é prioridade. As demais frentes de ação constam nos subprojetos. O controle da qualidade dos corpos d'água da região se faz sobretudo pelos bioindicadores.

\section{$\underline{\text { Subprojetos }}$}

A Bacia do Rio das Velhas ocupa uma área de drenagem de 29.000 km2. É uma região bastante grande e isso implica em problemas e necessidades das mais diversas, mesmo quando o objetivo principal é a recuperação e preservação do meio ambiente. Por isso foram criados 14 subprojetos dentro do Projeto Manuelzão, cada um direcionado para um problema específico. De modo geral, o objetivo desses subprojetos é alcançar o desenvolvimento sustentável e a sobrevivência dos ecossistemas da Bacia, melhorando a qualidade de vida da população com cidadania e saúde. São eles:

Arte \& Cultura;

Assistência Médica;

Comunicação;

Desmatamento;

Economia Rural;

Esgoto;

Educação;

Direito Ambiental;

Indústria;

Lixo;

Pesquisa;

Mananciais \& Cursos d'água;

SOS Rio das Velhas;

Turismo. 
ANEXO B

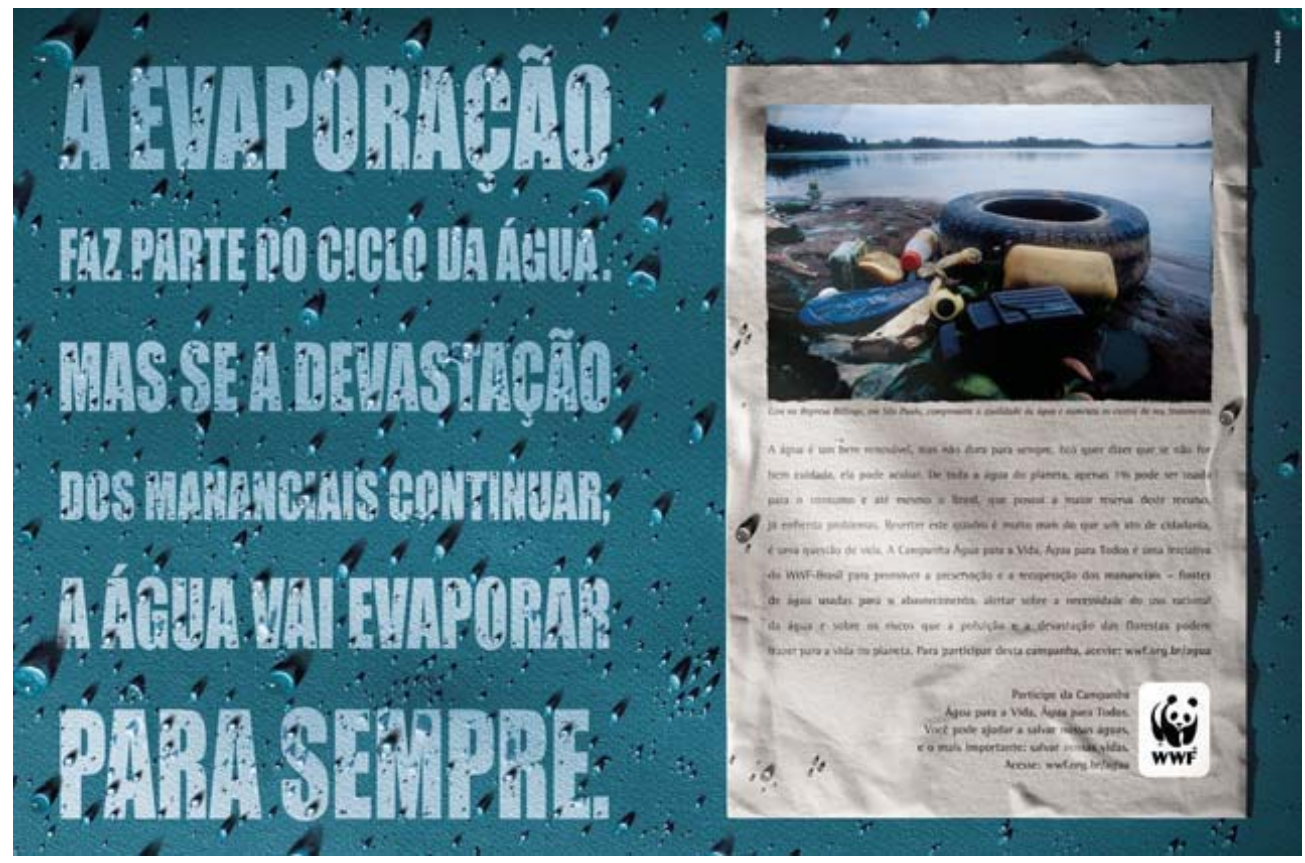

Peça 1 da Campanha.

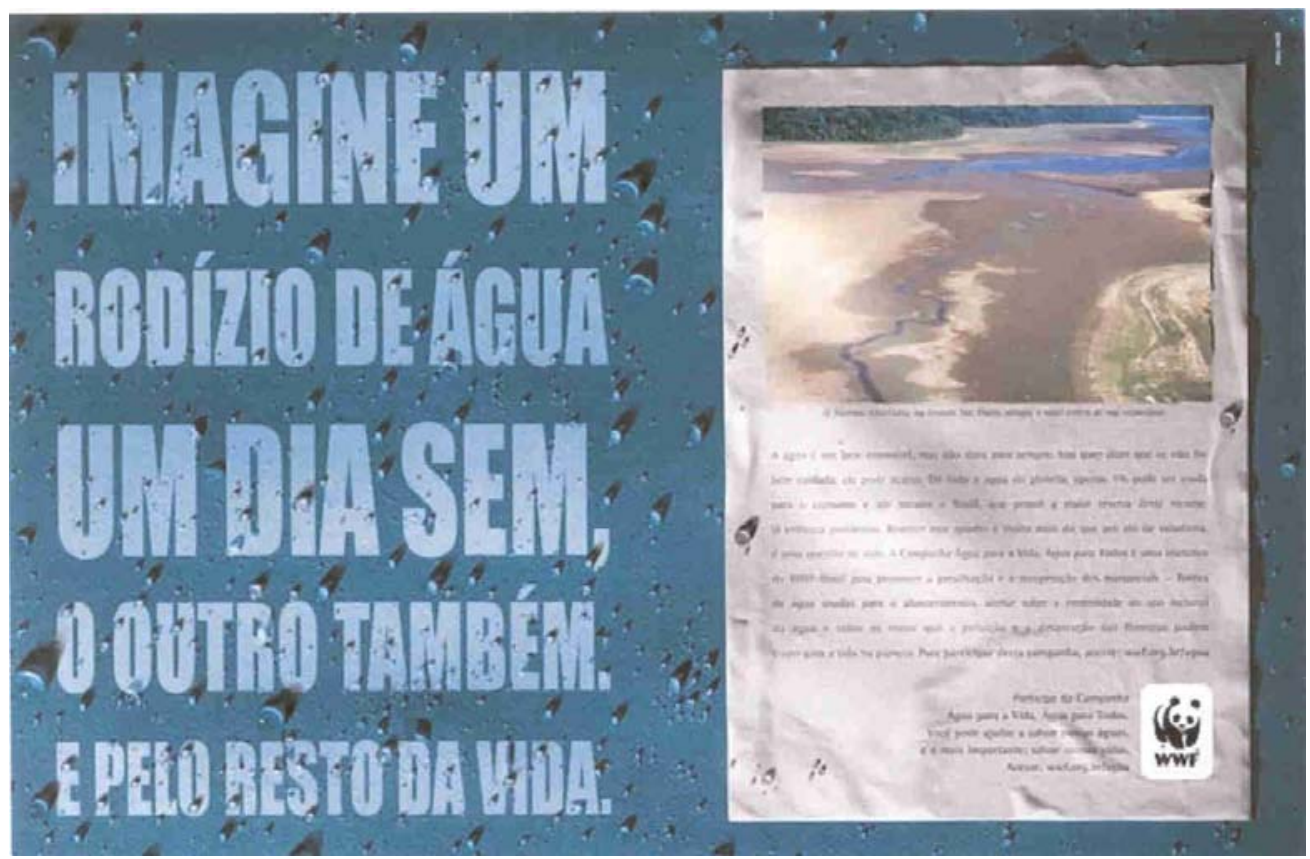

Peça 2 da Campanha. 


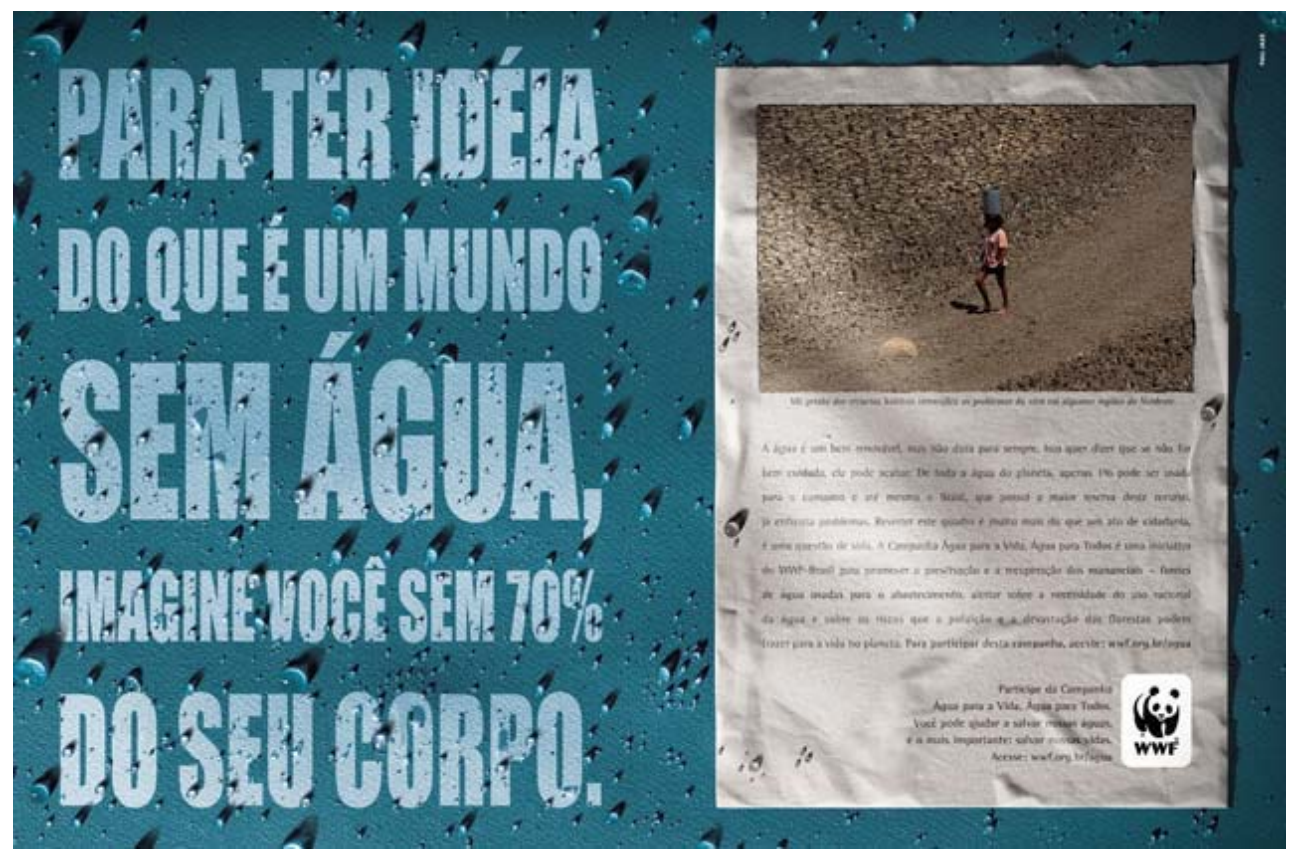

Peça 3 da Campanha.

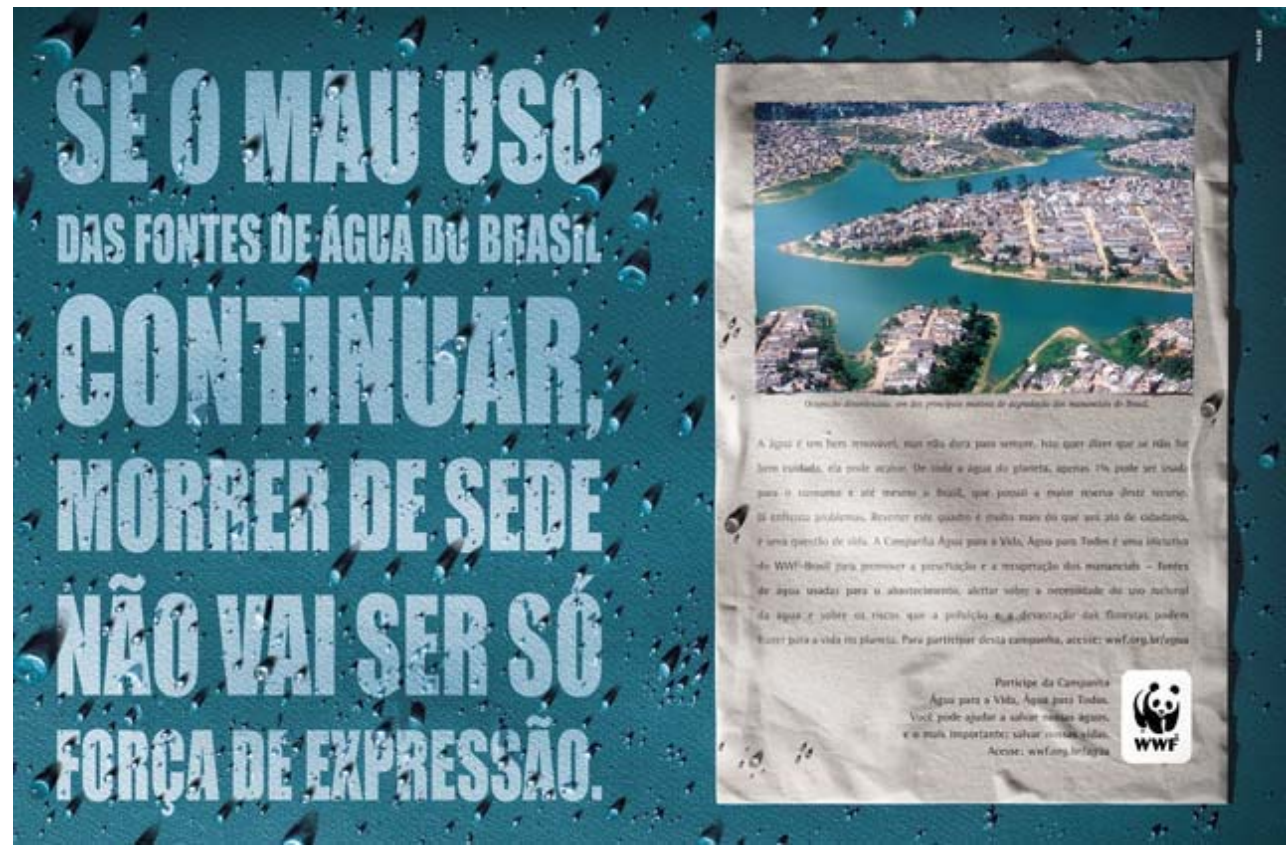

Peça 4 da Campanha. 